\title{
The Implied Warranty of Habitability: A New Doctrine Raising New Issues
}

\author{
Myron Moskovitz*
}

Professor Moskovitz has prepared a timely article on the implications of the recent California Supreme Court case, Green v. Superior Court, and its innovative doctrine, the use of an implied warranty of habitability as a defense to eviction for nonpayment of rent. The article explores the entire field-from what constitutes a breach to how protective orders are to be applied, even suggesting a creative solution to the difficult problem of measuring damages. Professor Moskovitz brings to this task long experience in both the study and the practice of landlord-tenant law; indeed, he co-argued the Green case. Drawing on his knowledge of litigation he has included throughout the article practical advice for the attorney immersed in landlord tenant matters. This advice is contained in textual footnotes; for ready identification each is set off by extra space and captioned "practice note."

Two years ago the Court of Appeal for the First District adopted a new doctrine in California, giving some hope of legal relief to residential tenants whose landlords refuse to repair and maintain rental premises. In Hinson v. Delis ${ }^{1}$ the court imposed an imphed warranty of habitability on all residential landlords, overruling the long-established common law rule that a landlord owes no duty to his tenant to repair and maintain the premises.

While Hinson arose in the context of a tenant's action for declaratory relief, the language and reasoning used by the court indicated a broader reach. Nevertheless, many trial court judges, unsympathetic to Hinson, chose to limit it to its facts, refusing for instance to allow breach of the warranty as a defense in an unlawful detainer action brought for nonpayment of rent. ${ }^{2}$ Such limitations were dispelled re-

* Associate Professor of Law, Golden Gate University; B.S. 1960, LL.B. 1964, University of California, Berkeley.

1. 26 Cal. App. 3d 62, 102 Cal. Rptr. 661 (1st Dist. 1972).

2. These actions are authorized by statute. CAL. CoDE CTv. Pro. $\$ \S 1161-79 a$ (West 1967, West Supp. 1973).

The court subsequeutly disposed of a court of appeal case which had limitcd Hinson by denying the warranty's use in defense to eviction. See, e.g., Murdock v. Lofton, 107 Cal. Rptr. 551 (1st Dist. 1973), vacated and remanded, Cal. Sup. Ct. (Feb. 21, 1973) (instructing the court of appeals to reconsider its decision in light of Green). 
cently by the California Supreme Court. In Green v. Superior Court $t^{3}$ the court adopted the implied warranty theory of Hinson and lield that it may be raised as a defense in an eviction action.

In adopting the implied warranty doctrine, the court in Green traced the old common law rule to its agrarian origin and discovered that it developed at a time when most leases were for agricultural land, with any simple structures on the land considered imcidental and easily repairable by the "jack-of-all-trades" tenant-farmer. The great majority of today's leases, however, are for urban dwelling units, "a package of goods and services" ${ }^{\prime 4}$ rather than mere space. Proper repair of these units requires specialized talents not possessed by the average tenant. ${ }^{5}$ The court took notice of: (l) the scarcity of adequate low-cost housing, leaving tenants little bargaining power with whicl to negotiate for proper maintenance and repair; ${ }^{6}$ (2) the widespread enactment of comprehensive housing codes in the past 50 years, demonstrating legislative recognition of the problem and the landlord's duty; (3) the recent surge in development of the law of consumers' rights generally (including the application of implied warranty theories to real estate transactions); $;^{8}$ and (4) the recent adoption of the implied warranty doctrine by the highest courts of seven states and the District of Columbia. ${ }^{9}$ The court went on to reject the contention that the legislature, through statutes granting the tenant a repair-and-deduct remedy where the landlord fails to repair, ${ }^{10}$ intended this to be the tenant's exclusive remedy, precluding recognition of a common law warranty of habitability. It reasoned that this very limited remedy was designed only for repairing minor dilapidations. Moreover, it noted that similar arguments had been rejected by the courts of other states which adopted the imphed warranty doctrine. ${ }^{11}$

Finally, the court held that the implied warranty doctrine can be raised as a defense in an eviction action based on nonpayment of rent

3. 10 Cal. 3d 616, 517 P.2d 1168, 111 Cal. Rptr. 704 (1974) (Tobriner, J., for a unanimous court).

4. Javins v. First Nat'l Realty Corp., 428 F.2d 1071, 1074 (D.C. Cir.), cert. denied, 400 U.S. 925 (1970), quoted in Green v. Superior Court, 10 Cal, 3d 616, 623, 517 P.2d 1168, 1172, 111 Cal. Rptr. 704, 708 (1974).

5. Id. at 622-25, 517 P.2d at 1171-73, 111 Cal. Rptr. at 707-09.

6. Id. at 625,517 P.2d at 1173,111 Cal. Rptr. at 709.

7. Id. at $627,517 \mathrm{P} .2 \mathrm{~d}$ at $1175,111 \mathrm{Cal}$. Rptr. at 711 .

8. Id. at $626-27,517$ P.2d at $1174-75,111$ Cal. Rptr. at 710-11.

9. Id. at 619 n.1, 628, 517 P.2d at 1169 n.1, 1175-76, 111 Cal. Rptr. at 705 n.1, 711-12. Since Green was argued, courts in other states have also adopted the doctrine. E.g., Steele v. Latimer, 214 Kan. 329, 521 P.2d 304 (1974); King v. Moorehead, 495 S.W.2d 65 (Mo. Ct. App. 1973); Foisy v. Wyman, 83 Wash. 2d 22, 515 P.2d 160 (1973).

10. Cal. Civ. Code $\$ \$ 1941-42.1$ (West 1970, West Supp. 1973).

11. 10 Cal. 3d at 629-31, 517 P.2d at 1177-78, 111 Cal. Rptr. at 713-14. 
for the period during which the warranty was allegedly breached. The court observed that affirmative defenses are allowed in eviction actions if they go to the issue of possession. Fornerly, the landlord's failure to perform any duty to maintain the premises (usually pursuant to an express covenant) was deemed imdependent of the tenant's duty to pay rent. Under this rule an alleged breach of the landlord's duty was irrelevant in an eviction action for nonpayment of rent, since this breach, even if proven, did not relieve the tenant of his separate duty to pay rent. The court in Green rejected the independent covenants rule. It arose, the court reasoned, at a time when the habitability of structures on farmland was only an incidental, nonmaterial term of the lease. Today, the court held, the habitability of the dwelling unit is the very essence of a residential lease. ${ }^{12}$

The procedure for raising the defense, as contemplated by Green and Hinson, nay be briefly summarized. The tenant first notifies the landlord of the defects. If the landlord fails to renedy the problems within a reasonable time, the tenant may stop paying rent until repairs are made, whereupon the obligation to pay the contract rent resumes. If the landlord sues to evict the tenant for nonpayment of the withheld rent, the tenant's answer may allege the facts constituting the breach of implied warranty. Under certain conditions the court may thereupon enter a protective order compelling the tenant to pay into court the rent as it comes due thereafter. If the tenant proves his defense at trial, the finder of fact must determine a reasonable rent for the period of the breach. The court then gives the tenant reasonable time to pay this sum to the landlord. Compliance by the tenant precludes eviction. ${ }^{13}$ Lastly, any money paid into court under a protective order is distributed to the parties according to the verdict. The landlord receives all of this fund if he wins; otherwise the tenant receives any. excess over the reasonable rent he owes.

The adoption of the implied warranty of habitability leaves unresolved several important questions involving the definition and scope of the doctrine, its remedies, and certain procedural problems. There is an additional issue: how will low-income tenants be able to use the implied warranty doctrine? Even tenants of moderate income generally lack the means to finance expensive eviction defense litigation, especially where the amount in dispute does not merit substantial investment. The Article attempts to foresee most of these problems

12. Id. at $631-35,517$ P.2d at 1178-81, 111 Cal. Rptr. at 714-17.

13. The tenant, upon paying the reasonable rent to the landlord, should be considered the prevailing party for purposes of awards of costs and attorneys fees. Sec M. Moskovitz, P. Honigsberg \& D. Finkelstein, Caitfornia Eviction Defense ManUAI $\$ \$ 15.20-.27$, at 150-51 (1971) [hereinafter cited as CAIIForNIA Eviction DefENSE Manual]. 
and to lay the groundwork for future development of the doctrine. Several jurisdictions have had the implied warranty for a few years; their decisions furnish helpful guidance on some issues. The majority of the issues, however, have not yet been examined in any depth and therefore several of the proposals which appear here are bemg made for the first time. If the reader finds some of them not wholly persuasive, it is hoped that they will at least stimulate efforts to improve them.

I

\section{SCOPE OF THE IMPLIED WARRANTY DOCTRINE}

Several courts which have adopted the implied warranty of habitability have made rulings relating to the ultimate reach of the doctrinean important issue-without adequate consideration of the many complex issues involved. At the outset, one can resolve certain questions of scope without great difficulty. For instance, it would appear quite clear that the doctrine should apply with equal force to single family dwellings and apartments alike. While Green, Javins v. First National Realty Corp..${ }^{14}$ and other cases adopting the implied warranty doctrime have involved apartments and stressed the problems of urban apartment dwellers, several cases have applied the doctrine to single family houses. ${ }^{15}$ Although none of these cases expressly discusses the point, ${ }^{16}$ application to houses and apartments without distinction seems well justified. Single family dwellings, after all, are covered by housing codes, and tenants in such dwellings face the same inequality of bargaining power as apartment dwellers. Certain factors relating to the apartment tenant's inability to repair are less likely to be mvolved in single family houses, ${ }^{17}$ but these differences seem insubstantial. The house dweller's ability to repair heating, wiring, and plumbing systems is, in reality, usually no better than that of the apartment-dweller. ${ }^{18}$

14. 428 F.2d 1071 (D.C. Cir.), cert. denied, 400 U.S. 925 (1970).

15. See Lemle v. Breeden, 51 Hawaii 426, 427, 462 P.2d 470, 471 (1969); Lund v. McArthur, 51 Hawaii 473, 462 P.2d 482 (1969); Mease v. Fox, 200 N.W.2d 791, 792 (Iowa 1972); Steele v. Latimer, 214 Kan. 329, —, 521 P.2d 304, 306 (1974); Glyco v. Schultz, 35 Ohio Misc. 25, 26, 289 N.E.2d 919, 921 (Sylvania Mun. Ct. 1972); Foisy v. Wyman, 83 Wash. 2d 22, -, 515 P.2d 160, 162 (1973); Pines v. Perssion, 14 Wis. 2d 590, 591, 111 N.W.2d 409, 410 (1961).

16. Cf. Jack Spring, Inc. v. Little, 50 Ill. 2d 351, 363, 280 N.E.2d 208, 221-22 (1972) (Ryan, J., dissenting).

17. In Green, for example, the court noted that "in a multiple-unit dwelling repair will frequently require access to equipment and areas solely in the control of the landlord." 10 Cal. 3d at 624, 517 P.2d at 1073, 111 Cal. Rptr. at 709.

18. Two additional issues concerning the doctrine's scope are its application to government owned housing and to commercial tenants. The fact that housing is owncd by the government sliould not exclnde it from the implied warranty doctrine. As a California appellate court observed in another context, "In the absence of a specific statute so declaring or agreement so specifying plaintiffs, as tenants, do not lose any of their 
A second issue is also easily disposed. Where the doctrine is accepted, landlords should not be permitted to require tenants to waive the imphied warranty as a condition to rental or lease. One of the bases for the doctrine's development is the inequality of bargaining power between landlord and tenant. ${ }^{19}$ Recognizing this inequality, Green and several other cases have expressly held that waiver provisions are invalid as contrary to public policy. ${ }^{20}$

rights merely because their landlord happens to be the State of California." Hubbs v. People ex rel. Dep't Pub. Wks., 36 Cal. App. 3d 1005, 1009, 112 Cal. Rptr. 172, 175 (1st Dist. 1974). See Knox Hill Tenant Council v. Washington, 448 F.2d 1045, 105657 (D.C. Cir. 1971); cf. Davis v. Romney, 490 F.2d 1360 (3d Cir. 1974); City of Philadelphia v. Page, 363 F. Supp. 148 (E.D. Pa. 1973) (holding HUD to an implied warranty of habitability in its sale of homes). See also Coleman v. United States, 311 A.2d 496 (D.C. Ct. App. 1973). In California, moreover, the implied warranty doctrine should apply to pnblic housing authorities since the state's Health and Safety Code expressly requires them to comply with all local sanitary and building regulations. CAL. HEALTH \& SAFETY CoDE $\$ 34326$ (West 1964).

On the other hand, applying the doctrine to commercial tenants might seem beyond the doctrine's underlying rationale, as building maintenance codes do not always apply to commercial premises, and as one would not expect to find pervasive inequality of bargaining power in commercial landlord-tenant relationships. Nevertheless, the New Jersey Supreine Court, without discussing the point, did apply the doctrine in a commercial setting. Reste Realty Corporation v. Cooper, 53 N.J. 444, 251 A.2d 268 (1969). A later New Jersey case implies that a commercial tenant can raise breach of warranty as a defense in an eviction case. Demirci v. Burns, 124 N.J. Super. 274, 306 A.2d 468 (App. Div. 1973). But see Interstate Restaurants, Inc. v. Halsa Corp., 309 A.2d 108, 110-11 (D.C. Ct. App. 1973).

19. See note 37 infra.

20. 10 Cal, 3d at 625 n.9, 517 P.2d at 1073 n.9, 111 Cal. Rptr. at 706 n.9; Javins v. First Nat'1 Realty Corp., 428 F.2d 1071, 1081-82 (D.C. Cir.), cert. denied, 400 U.S. 925 (1970); Boston Housing Authority v. Heuningway, -Mass. -, -, 293 N.E.2d 831, 843 (1973); cf. Steinberg v. Carreras, 74 Misc. 2d 32, 38, 344 N.Y.S.2d 136, 141-42 (N.Y. City Civ. Ct. 1973) (criticizing form rental agreements favoring landlords). But see Mease v. Fox, 200 N.W.2d 791, 797 (Iowa 1972), suggesting that the breach might not be material if the tenant "voluntarily, knowingly and intelligently waived the defects." The court did not explain what it meant by voluntarily, but this term should not be construed to permit waivers where the tenant accepts the waiver because of unequal bargaining power. Compare note 37 infra. See also Buckner v. Azulai, 251 Cal. App. 2d 1013, 1015, 59 Cal. Rptr. 806, 808 (L.A. Super. Ct. App. Dep't 1967); Berzito v. Gambino, 114 N.J. Super. 124, 129, 274 A.2d 865, 868 (Dist. Ct. 1971), aff'd, 63 N.J. 460, 308 A.2d 17 (1973).

A somewhat related issue questions the doctrine's use with premises which become uninhabitable after the tenant is required to vacate. Suppose, for example, that the tenant fails to pay the March rent on March 1, when it is due. On March 5, he receives a 3-day notice to pay or quit. On March 8, he has failed to do either. On March 9, the landlord commits acts which would coustitute a breach of the implied warranty of habitability. Should the warranty extend to this holdover period? If it does, then the tenant can raise the implied warranty as a defense to an eviction action based on nonpayment of the March rent. Since the warranty was breached in March, he owed only a reasonable rent for that month, not the contract reut due in advance on March 1.

On the one hand, Green's holding that lease covenants are mutually dependent would seem to relieve the landlord of his duty to comply with the warranty if the tenant unjustifiably has failed to comply with his duty to pay rent. The court did not address 
Other issues of the doctrine's scope are not resolved so simply. One of these is the doctrine's application to premises uninhabitable at the inception of the tenancy. More particularly the issue can be framed in these terms: should a tenant wlio presumably knew of and accepted defects existing at the outset be allowed to use the implied warranty subsequently as a defense to eviction based on nonpayment of rent? The answer requires responses to several intermediate questions. What are the underlying purposes of the implied warranty doctrine pertinent to this issue? What troubling consequences might result from the doctrine's use, without modification, for premises defective at the inception of the tenancy? And how can one prevent such threatened consequences short of abandoning the doctrine altogether?

Housing codes, and the public policy behind them, have played a vital role in developing the doctrine. Accordingly, they offer insight into the purposes underlying the implied warranty and supply the foundation for analyzing this issue. Green and the cases on which it relied based their adoption of the implied warranty doctrine partly on the fact that legislatures, in enacting housing codes, liave expressed a public policy that certain housing standards must be inaintained. Thus, reasoned the cases, giving tenants the implied warranty doctrine and its attendant remedies will encourage landlords to obey these housing standards. It follows that removing any dwelling units in violation of these standards from the scope of the doctrine would diminish the effectiveness of this purpose of the implied warranty doctrine. Therefore, the doctrine should apply to premises defective at the outset. ${ }^{21}$

this issue, however, and a case may be made for the tenant by arguing that he is still a tenant during this period, and therefore entitled to the benefits of the rental agreement. See Kulawitz v. Pacific Woodenware \& Paper Co., 25 Cal. 2d 664, 670, 155 P.2d 24, 27 (1944) (tenant's failure to pay rent did not relieve landlord of obligation to comply with restrictive covenant in lease, "unless the lease provides expressly or by necessary implication that performance thereof depends upon the payment of rentals."). While the landlord can take judicial action against the tenant, he cannot use any form of selfhelp against him. Jordan v. Talbot, $55 \mathrm{Cal} .2 \mathrm{~d} 597,361$ P.2d 20, $12 \mathrm{Cal}$. Rptr. 488 (1961). The housing codes do not abate during a tenant holdover, and the danger to the community from substandard housing is just as great. See City of Dover v. BCP Realty, 112 N.H. 238, 293 A.2d 599 (1972), where the court upheld the conviction of a landlord for violating housing codes during the tenant's improper holdover. In short, the reasons why the implied warranty doctrine was adopted seem to apply just as strongly here.

If, however, the landlord can show that the tenant's holdover itself caused the landlord to breach the warranty, then perhaps the tenant should be estopped from asserting the doctrine. This might occur, for instance, where a very marginal landlord becomes unable to make needed repairs or provide required maintenance precisely because he lacks the money which would have come from the tenant's payment of the rent due or from a new tenant, if thc old tenant had vacated instead of holding over.

21. It has been suggested that failure to apply it at the inception might even encourage landlords to keep their premises in disrepair, so that new tenants could not use the impled warranty doctrine. 84 HARv. L. REv. 729, 736 (1971). 
Indeed, it should be noted that none of the out-of-state cases which adopted the implied warranty doctrine has held that the warranty does not apply to premises defective at the outset, ${ }^{22}$ and in fact several have held, expressly ${ }^{23}$ or impliedly, ${ }^{24}$ that it does so apply.

In Green, however, although it was not required to (and in fact did not) rule directly on this issue, ${ }^{25}$ the court expressed some desire to limit the doctrine's application where premises are uninhabitable at the inception of the tenancy. ${ }^{26}$ The court's concern, it appears, is that allowing use of the doctrine in such circumstances might enable or even encourage scheming tenants to set up a landlord for rent withholding. ${ }^{27}$ In sidestepping the issue the court suggested that a lease executed under such conditions might be an illegal contract or, that the tenant might have assumed the risk of uninhabitable premises. ${ }^{28}$

The California Supreme Court's concern over the scheming tenant seems exaggerated. It would be a rare tenant who would combine all the attributes which the court fears: the prerequisite evil motive, a need sufficiently great to warrant the legal and personal struggles which must result, and the knowledge, sophistication and skill necessary for successfully commencing and maintaining a rent withholding plan. Still, it is conceivable that the doctrine could be abused, as for instance where a tenant who can clearly afford decent housing deliberately seeks out substandard housing with a plan of later asserting the implied warranty doctrine to withhold rent or sue the landlord. Solutions for such abuses, superior to those suggested by the court, however, are available. The theories of estoppel ${ }^{20}$ and unclean

22. See, e.g., Berzito v. Gambino, 114 N.J. Super. 124, 129, 274 A.2d 865, 868 (Dist. Ct. 1971), aff'd, 63 N.J. 460, 308 A.2d 17(1973), which also noted the issue need not be decided.

23. Mease v. Fox, 200 N.W.2d 791, 796 (Iowa 1972) (warranty covers only latent defects at outset); Boston Housing Authority v. Hemingway, - Mass. —, -, 293 N.E.2d 831, 843 (1973) (patent as well as latent defects covered); King v. Moorehead, 495 S.W.2d 65, 75 (Mo. Ct. App. 1973); Kline v. Burns, 111 N.H. 87, 92, 276 A.2d 248, 252 (1971); Marini v. Ireland, 56 N.J. 130, 144, 265 A.2d 526, 534 (1970); Samuelson v. Quinones, 119 N.J. Super. 338, 291 A.2d 580 (App. Div. 1972); Glyco v. Schultz, 35 Ohio Misc. 25, 29, 289 N.E.2d 919, 925 (Sylvania Mun. Ct. 1972); Foisy v. Wyman, 83 Wash. 22, -, 515 P.2d 160, 164 (1973).

24. See Lemle v. Breeden, 51 Hawaii 426, 462 P.2d 470 (1969); Gillette v. Anderson, 4 IIl. App. 3d 838, 282 N.E.2d 149 (1972); Pines v. Perssion, 14 Wis. 2d 590, 11 N.W.2d 409 (1961). In these cases, the defects were alleged to be present at tho outset. Nevertheless, the courts, adopted the implied warranty doctrine without discussing the point.

25. 10 Cal. $3 d$ at 621 n.3, 512 P.2d at 1070-71 n.3, 111 Cal. Rptr. at 706-07 n.3.

26. Id.

27. This concern may be inferred from the questions asked from the bench during oral argument in Green, especially those of Chief Justice Wright.

28. $10 \mathrm{Cal} .3 \mathrm{~d}$ at $621 \mathrm{n.3}, 517 \mathrm{P} .2 \mathrm{~d}$ at $1070-71 \mathrm{n.3}, 111 \mathrm{Cal}$. Rptr. at 706-07 n.3.

29. Estoppel is available against the landlord in unlawful detainer cases. Salton 
hands, ${ }^{30}$ for example, seem better tailored to the court's concern than either illegal contract or assumption of risk. Using these equitable theories the court can remedy the abuses without depriving the great bulk of innocent tenants of the benefits of the doctrine.

The court's possible adoption of assumption of risk, as modifying the doctrine's application to premises defective at the outset, may in any event pose few problems for the typical tenant. Conceivably the court, on more thorough analysis, may find the assumption of risk theory inapplicable to this setting, since it would intrude on the two apparent purposes of the housing codes: to protect the tenant from his inability to protect himself through bargaining, and to protect the commumity from the social and liealth dangers from substandard housing. As to the first purpose, Prosser notes that the assumption of risk doctrine is not applicable to statutes "intended to protect the plaintiff against his own imability to protect himself, including his own lack of judgment or imability to resist various pressures."31 As to the second purpose, the Washington Supreme Court recently held that the implied warranty applied at the inception of the tenancy, even where the tenant then knew of the defects and in fact bargained for a lower rent because of them. ${ }^{32}$ Indeed, the rationale of Green itself supports such a finding of inapplicability. Green and the cases on which it relied adopted the impled warranty doctrine at least partly to encourage landlords to maintain those housing standards enbodied in housing

Community Services Dist. v. Southhard, 256 Cal. App. 2d 526, 531, 64 Cal. Rptr. 246, 250 (4th Dist. 1967). In Mease v. Fox, 200 N.W.2d 791, 797 (Iowa 1972), the court suggested that the tenant might be estopped from asserting the implied warranty doctrine in some circumstances. Also, without indicating the applicable theory, some cases have indicated that the tenant could not raise the doctrine if lie caused the defects by abnorinal use. See Himson v. Delis, 26 Cal. App. 3d 62, 70, 102 Cal. Rptr. 661, 666 (1st Dist. 1972); Boston Housing Authority v. Hemingway, -Mass. -, —, 293 N.E.2d 831, 844 (1973).

30. Bad faith or inequitable conduct of the landlord are available defenses in unlawful detainer cases. See Strom v. Umion Oil Co., 88 Cal. App. 2d 78, 198 P.2d 347 (1st Dist. 1948); Knight v. Black, 19 Cal. App. 518, 126 P. 512 (1st Dist. 1912).

31. W. Prosser, The LAw of ToRTs 453 (4th ed. 1971). See also Finnegan v. Royal Realty Co., 35 Cal. 2d 409, 431, 218 P.2d 17, 30-31 (1950).

32. We believe this type of bargaining by the landlord with the tenant is contrary to public policy and the purpose of the doctrine of implied warranty of habitability. A disadvantaged tenant slould not be placed in a position of agreeing to live in an uninhabitable premises. Housing conditions, such as the record indicates exist in the instant case, are a health lazard, not only to the individual tenant, but to the community which is exposed to said individual .... [S] uch lousing conditions are at least a contribnting cause of such problems as urban blight, juvenile delinquency and high property taxes for the conscientious landowners.

Foisy v. Wyman, 83 Wash. 2d 22, -, 515 P.2d 160, 164-65 (1973). But see id at -, 515 P.2d at 169 (dissenting opinion). See also Javins v. First Nat'l Realty Corp., 428 F.2d 1071, 1079-80 (D.C. Cir.), cert. denied, 400 U.S. 925 (1970) ("poor housing is detrinental to the whole society"). 
codes. ${ }^{33}$ Application of assumption of risk rules could remove from the scope of the doctrine at least some premises which violate these standards at the imception of the tenancy, and could thus dimimish the effectiveness of this purpose of the implied warranty doctrine.

Moreover, even if found apphicable, there still remain several reasons why standard assumption of risk rules will seldoin, if ever, bar the tenant from using the implied warranty doctrine at the outset of the tenancy. First, in order for the doctrine to be applicable a tenant "must know and understand the risk he is incurring." it is unlikely that a prospective tenant will discover major, latent defects in wiring and plumbing and the like on a brief imitial inspection, ${ }^{35}$ this limitation probably removes from the grasp of the assumed risk doctrine the great majority of cases where defects exist at the outset. Second, even with known defects the tenant does not assume the risk unless his choice of renting the dwelling is "a free and voluntary one."30 In the present rental market, such free and voluntary choices are rare. As the court in Green observed, "[t] $]$ he severe shortage of low and moderate cost housing has left tenants with little bargaining power .... [E]ven when defects are apparent the low income tenant frequently has no realistic alternative but to accept such housing with the expectation that the landlord will make the necessary repairs."

Treating the lease as an illegal contract, on the other hand, would appear completely to avoid the assumption of risk theory, since illegal contract doctrine is based not on an attempt to achieve justice between the parties, but on the court's policy of refusing to encourage the making of such contracts by enforcing them. ${ }^{88}$ Therefore, a tenant's conduct is irrelevant if the contract is otherwise illegal. Using the illegal

33. See notes 7, 21 supra and accompanying text.

34. W. Prosser, THe LAW OF TORTS 447 (4th ed. 1971); 4 B. WitkIN, CaliforNIA LAW 2451 (8th ed. 1974).

35. In Green the court acknowledged that "the increasing complexity of modern apartment buildings . . . makes adequate inspection of the premises by a prospective tenant a virtual impossibility; complex heating, electrical and plumbing systems are hidden from view ..."10 Cal. 3d at 624, 517 P.2d at 1073, 111 Cal. Rptr. at 709. See also Javins v. First Nat'1 Realty Corp., 428 F.2d 1071, 1079 n.42 (D.C. Cir.), cert. denied, 400 U.S. 925 (1970) ("Nor should the average tenant be thought eapable of "inspecting' plaster, floorboards, roofing, kitchen appliances, etc."); Note, Landlord and Tenant: Repairing the Duty to Repair, 11 SANTA CLARA LAw. 298, 312 (1971).

36. W. PROSSER, THE LAW OF TORTS 450 (4th ed. 1971).

37. $10 \mathrm{Cal} .3 \mathrm{~d}$ at $625,517 \mathrm{P} .2 \mathrm{~d}$ at $1074,111 \mathrm{Cal}$. Rptr. at 710 . See also Javins v. First Nat'1 Realty Corp., 428 F.2d 1071, 1079 n.42 (D.C. Cir.), cert. denied, 400 U.S. 925 (1970); Lemle v. Breeden, 51 Hawaii 426, 431, 462 P.2d 470, 473 (1969) (fair to presume that no individual would voluntarily choose to live in an unsafe dwelling); Reste Realty Corp. v. Cooper, 53 N.J. 444, 452, 251 A.2d 268, 272 (1969); Note, supra note 35 , at 306-08 (regarding the scarcity of such housing in California).

38. Lewis \& Queen v. N.M. Ball Sons, 48 Cal. 2d 141, 150, 308 P.2d 713, 719 (1957); Shephard v. Lerner, 182 Cal. App. 2d 746, 750, 6 Cal. Rptr. 433, 435 (1st Dist. 1960). 
contract theory, one may argue that, on either of two grounds, a lease is void where executed for premises defective at the outset. First, where the housing code specifically prohibits the rental of a dwelling with code violations, the contract is illegal. ${ }^{39}$ Such prohibitions are common, and have been present in most of the cases that have applied the illegal contract theory to residential tenancies. ${ }^{40}$ Indeed, California has such a provision in its state housing law. ${ }^{41}$ Second, even without such a specific regulatory prohibition, a contract is illegal if it contemplates performance in an illegal manner. ${ }^{42}$ Therefore, the contract is void if the landlord knows that the premises he will supply the tenant under the agreement are presently in violation of the housing code. ${ }^{43}$

While the above authorities show that the implied warranty of habitability and the illegal contract doctrine should each apply to premises which violate the housing codes at the inception of the tenancy, it might appear that the latter logically precludes the former. If the contract is illegal, how can the tenant claim benefits under an implied warranty arising from that contract? The question seeins academic unless the consequences of adopting one theory differ from those flowing from the other. So far, however, the few courts adopting

39. Brown v. Southall Realty Co., 237 A.2d 834 (D.C. Ct. App. 1968); Longenecker v. Hardin, 130 IIl. App. 2d 468, 264 N.E.2d 878 (1970); Glyco v. Schultz, 35 Ohio Misc. 25, 30, 289 N.E.2d 919, 923-24 (Sylvania Mun. Ct. 1972); Jensen v. Salisbury, 1 CCH Pov. L. Rep. II 2210.043 (Conn. Cir. Ct. 1968).

40. See Brown v. Southall Realty Co., 237 A.2d 834 (D.C. Ct. App. 1968); Longenecker v. Hardin, 130 Ill. App. 2d 468, 264 N.E.2d 878 (1970); Glyco v. Schultz, 35 Ohio Misc. 25, 289 N.E.2d 919 (Sylvania Mun. Ct. 1972).

41. The Department of Housing and Community Development is authorized to enact housing regulations. CAL. Health \& SAfETy Code $\$ 17921$ (West 1964). The Department, pursuant to this authorization, has adopted the Uniform Housing Code. 25 CAL. AdMIN. CoDE $\$ 1060$ (West 1974). Section 204 provides im part:

No person, firm, or corporation, whether as owner, lessee, sublessee, or occupant, shall ... use, occupy, or maintain any building or premises, or cause or permit the same to be done, contrary to or in violation of any of the provisions of this Code.

UNIFORM HOUSING CODE \$204.

42. Howell v. City of Hamburg, 165 Cal. 172, 131 P. 130 (1913); Shephard v. Lemer, 182 Cal. App. 2d 746, 6 Cal. Rptr. 433 (1st Dist. 1960); 30 CaL. JuR. 2d Landlord and Tenant $\$ 37$ (Supp. 1974).

43. In Hinson, however, the court indicated that Shephard v. Lerner, $182 \mathrm{Cal}$. App. 2d 746, 6 Cal. Rptr. 433 (1st Dist. 1960), and most of the other illegal contract cases are distinguishable, because in those cases "both parties knew of and willingly acquiesced in the illegality." Hinson v. Dehs, 26 Cal. App. 3d 62, 67, 102 Cal. Rptr. 661, 664 (1st Dist. 1972). Requiring the tenant as well as the Iandlord to know of the code violations in order to hold the lease illegal seems logically unsound. The purpose of the illegal contract doctrine-to discourage such contracts-is just as applicable where the tenant is not aware of the violations, and it would seem anomalous to grant the knowing tenant the benefits of the doctrine but deny them to the unknowing (and perhaps deceived) tenant, where the landiord's intentions are to violate the law in both cases. Moreover, while the tenant did know of the violations in Shephard, the court did not indicate that this fact was essential to its holding. 
the illegal contract approach have found ways to achieve the same results as those reached by courts using the implied warranty doctrine. For example, some courts have reasoned that since the tenant "had no real choice but to acquiesce in the illegality," and because the housing codes were adopted for his protection, the tenant is not in pari delicto with the landlord and can claim recovery of rents paid under the lease. ${ }^{44}$ But even though the lease is illegal, the reasoning has continued, the tenant took possession of the premises with the landlord's consent, thereby becoming a tenant at sufferance, and therefore he owes the landlord a reasonable rent for the premises in the condition in which they were occupied. ${ }^{45}$ Thus, the tenant's ability to defend or sue using the illegal contract theory and his measure of damages appear identical to those under the implied warranty theory. Moreover, it seems likely that the same standards used for ascertaining whether the warranty is breached will also be applied to determine whether code violations are serious enough to consider the lease an illegal contract. ${ }^{46}$

Despite the similarity between the results obtained through use of the illegal contract theory and those achieved by using the implied warranty doctrine, there are reasons why implied warranty should nonetheless be preferred. The developinent of the law concerning tenant's rights to habitable premises has been confused and perhaps retarded by courts' atteinpts to apply various legal theories not specially suited to the problem. ${ }^{47}$ Since the implied warranty theory has been accepted, however, the courts have been able to put aside as judicial fictions such theories as constructive eviction and partial actual eviction, for they are unnecessary when the implied warranty doctrine is available. ${ }^{48}$ Because use of the illegal contract theory may cause similar problems, without any apparent offsetting benefits, it too should be put aside, making way for the developinent of a doctrine whose parameters are difficult enough to set without the added complexities caused by a coinpeting legal theory.

44. Glyco v. Schultz, 35 Ohio Misc. 25, 30, 289 N.E.2d 919, 924 (Sylvania Mun. Ct. 1972).

45. William J. Davis, Inc. v. Slade, 271 A.2d 412, 416 (D.C. Ct. App. 1970). See also Glyco v. Schultz, 35 Ohio Misc. 25, 31, 289 N.E.2d 919, 924 (Sylvania Mun. Ct. 1972).

46. See Watson v. Kotler, 264 A.2d 141 (D.C. Ct. App. 1970), which held the contract not illegal where the landlord was making repairs at the time the tenant took possession, and later completed them within the reasonable time required by the housing code. Compare text accompanying notes 90-95 infra.

47. See, e.g., East Haven Associates, Inc. v. Gurian, 64 Misc. 2d 276, 313 N.Y.S.2d 927 (N.Y. City Civ. Ct. 1970) (constructive eviction doctrine expanded to cover "partial constructive eviction").

48. Hinson v. Delis, 26 Cal. App. 3d 62, 69-70, 102 Cal. Rptr. 661, 666 (1st Dist. 1972); Lemle v. Breeden, 51 Hawaii 426, 435, 462 P.2d 470, 475 (1969). 


\section{II}

\section{BREACH OF THE IMPLIED WARRANTY}

What constitutes a breach of the implied warranty of habitability depends, first, on what constitutes "habitable" premises. Habitable must mean something more than merely a dwelling in which the tenant can survive, for otherwise the mere fact that the tenant inhabited the premises would prove their habitability. ${ }^{49}$ Beyond this, however, the courts have so far found it difficult to articulate a precise test; they have stressed that "each case must turn on its own facts"so in determining whether the premises were rendered "uninhabitable in the eyes of a reasonable person." ${ }^{1}$ Nevertheless, several of the cases read together offer some guidance as to how the courts will apply the doctrine in terms of what facilities ${ }^{52}$ of the premises are covered by the warranty and how serious defects in these facilities must be in order for there to be a breach of the warranty.

\section{A. Facilities Covered by the Warranty}

In deciding which facilities are covered by the warranty, courts are agreed at least as to the location of such facilities. Facilities located within the tenant's apartment are of course covered. Moreover, since the tenant's health and safety might be seriously threatened by defects in such common areas as stairs, hallways and yards, the warranty should include, under this reasoning, facilities within the common areas he uses. ${ }^{53}$ Indeed, in some instances defective facilities even beyond the tenant's apartment and the common areas he uses might endanger his health and safety, as, for example, where serious fire hazards or defective main water pipes or central heating systems exist in areas controlled by the landlord and not open to the tenant.

The types of facilities covered by the implied warranty are those affected by "applicable building and housing code standards which

49. One Georgia case, however, has taken this position. See Morris v. Jones, 128 Ga. App. 847, -, 198 S.E.2d 354, 355 (1973). In Lemle v. Breeden, 51 Hawaii 426, 435,462 P.2d 470,475 (1969), the court called this an "absurd proposition, contrary to modern urban realities."

50. Lemle v. Breeden, 51 Hawaii 426, 436, 462 P.2d 470, 476 (1969).

51. Berzito v. Gambino, 63 N.J. 460, 469, 308 A.2d 17, 22 (1973).

52. "Facilities" is meant here to include not only specific physical facilities, but also aspects of the preinises meriting protection. For example, it includes general protection of the entire premises from a specific lazard (such as rodents or weather) as well as a toilet or kitchen.

53. See Javins v. First Nat'1 Realty Corp., 428 F.2d 1071, 1082 n.62 (D.C. Cir.), cert. denied, 400 U.S. 925 (1970); Hinson v. Delis, 26 Cal. App. 3d 62, 70, $102 \mathrm{CaI}$. Rptr. 661, 666 (1st Dist. 1972); King v. Moorelead, 495 S.W.2d 65, 76 (Mo. Ct. App. 1973). 
materially affect health and safety." 54 Of course, not every facility in a residence has the requisite material effect on health and safety, but many do. ${ }^{55}$ For example, health and safety certainly are affected materially by insect or rodent infestation, hazardous common areas, madequate room size, light, or ventilation, defective bathroom fixtures or kitchen facilities, insufficient or nonexistent hot and cold running water, insubstantial weather protection or heating, dangerous electrical outlets, light fixtures, or wiring, or inadequate emergency exits, fireresistant materials or fire-extinguishing systems. Accordingly, a tenant threatened by such defects could offer as evidence of the landlord's breach the applicable housing code standards regulating the facilities in question. ${ }^{56}$

54. Green v. Superior Court, 10 Cal. 3d 616, 637, 517 P.2d 1168, 1183, 111 Cal. Rptr. 704, 719 (1974); cf. Glyco v. Schultz, 35 Ohio Misc. 25, 29, 289 N.E.2d 919, 925 (Sylvania Mun. Ct. 1972). See also Javins v. First Nat'1 Realty Corp., 428 F.2d 1071, 1077 (D.C. Cir.), cert. denied, 400 U.S. 925 (1970); Hinson v. Delis, 26 Cal. App. 3d 62, 70, 102 Cal. Rptr. 661, 666 (1st Dist. 1972); Jack Spring, Jnc. v. Little, 50 Ill. 2d 351, 366, 280 N.E.2d 208, 217 (1972); Mease v. Fox, 200 N.W.2d 791, 796 (Iowa 1972); Boston Housing Authority v. Hemingway, - Mass. -, -, 293 N.E.2d 831, 844 n.16 (1973); King v. Moorehead, 495 S.W.2d 65, 75 (Mo. Ct. App. 1973); Morbeth Realty Corp. v. Velez, 73 Misc. 2d 996, 343 N.Y.S.2d 406, 410 (N.Y. City Civ. Ct. 1973).

55. To help resolve this issue the court in Green observed:

We also beheve that the staudards of "tenantability" set out in Civil Code section 1941.1, though not strictly applicable in this context of their own force, may provide some helpful guidance in determining whether a landlord has satisfied the common law warranty of habitability.

10 Cal. 3d at 637 n.23, 517 P.2d at 1183 n.23, 111 Cal. Rptr. at 719 n.23.

This "helpful guidance," however, inust not be misread as limiting the facilities covered by the implied warranty to those imcluded in Civil Code section 1941.1, namely, weather protection, plumbing, hot and cold running water, heating, lighting and wiring, clean grounds, adequate garbage receptacles, and safe floors, stairs, and railings. The Uniform Housing Code imcludes facilities which obviously materially affect health and safety, but which section 1941.1 fails to mention. Adequate room size, emergency exits, and fire protection are but several examples. See California's New Legislation on a Landlord's Duty to Repair, 3 U.C. Davs L. REv. 131, 146-47 (1971). These might have been excluded from section 1941.1, not because they do not seriously affect the health and safety of the occupants, but because the use of one month's rent to "repair and deduct" would not go very far to repair such costly facilities. (Although the same might be said of certain other facilities, perhaps there is a difference in degree, especially with room size defects). Green itself acknowledged this limitation of the repair-and-deduct remedy and used it as a basis for holding that the tenant needed the more extensive remedies available under the common law implied warranty doctrine, $10 \mathrm{Cal}$. 3d at $630-31,517$ P.2d at $1177,111 \mathrm{Cal}$. Rptr. at 713. Therefore, it would indeed be ironic if the implied warranty doctrine did not cover facilities affecting the tenant's health and safety, covered by the Uniform Housing Code, but not covered by the repair-and-deduct remedy.

56. These defects are covered by sections $201(\mathrm{c}), 503,504,505(\mathrm{a}),(\mathrm{c}),(\mathrm{d})$, 601(b), 701(a), (b), and 801 of the Uniform Housing Code, which California's Commission of Housing and Community Development has enacted. See noto 41 supra. Whilo the Commission has also adopted a few requirements of its own, including a requirement that the landlord furnish garbage receptacles, it has rehed mostly on incorporation of 
Housing code standards should not, however, be viewed as an exhaustive list of which facilities are includable. Admittedly, including within the purview of the implied warranty doctrine certain facilities not covered by the codes inay appear to go beyond one of the bases for court decisions adopting the implied warranty doctrine: the public policy expressed in a legislature's decision to enact housing codes. ${ }^{57}$ Other landlord-tenant legal theories, lowever, are not limited to facilities covered by the codes. For example, the tenant inay clain constructive eviction for serious defects in facilities outside the codes $^{53}$ or may in soine circumstances sue in negligence for personal injuries resulting from such defects. ${ }^{59}$ It would seein anomalous, therefore, to exclude from the implied warranty doctrine facilities which the courts have already decided nnay bring about the possibly more serious consequences of constructive eviction and personal injury suits. Moreover, there is case support for the proposition that the housing codes serve not as an outer boundary of which facilities are includable, but rather as a starting point in that determination. Some cases hold, for instance, that the codes provide merely threshold requirements ${ }^{60}$ or minimal standards, ${ }^{61}$ while others apparently have applied the implied

the standards in the Uniform Housing Code. See 25 CAL. ADMnN. CoDE $\$ \S 1060,1060.1$ (1974). A copy of the Uniform Housing Code can be obtained from the International Conference of Building Officials, 5360 South Workman Mill Road, Whittier, California 90601. Over 90 percent of California's cities and counties use this Code.

57. See notes $7 \& 21$ supra and accompanying text.

58. See, e.g., McDowell v. Hyman, 117 Cal. 67, 48 P. 984 (1897).

59. See, e.g., Clarke v. O'Connor, 435 F.2d 104 (D.C. Cir. 1970).

60. In Baston Housing Authority v. Hemingway, the only case to speak directly on this issue, the court stated:

The State Sanitary Code minimum standards of fitness for human habitation and any relevant local health regulations provide the trial court with the threshold requirements that all housing must meet. Proof of any violation of these regulations would usually constitute coinpelling evidence that the apartInent was not in habitable condition, regardless of whether the evidence was sufficient proof of a constructive eviction under our old case law. However, the protection afforded by the implied warranty or [sic] habitability does not necessarily coincide with the Code's requirements. There inay be instances where conditions not covered by the Code regulations render the apartment uninhabitable. Although we have eliminated the defence of constructive eviction in favor of a warranty of habitability defence, a fact situation, which could have demonstrated a constructive eviction, would now be sufficient proof of a inaterial breach of the warranty of habitability, regardless of whether a sanitary code violation existed or not.

- Mass. -, -, 293 N.E.2d 831, 844 n.16 (1973). A dissent disagrees, claiming that extension of the doctrine beyond the codes will cause too much uncertaiuty. "This deliberate creation of a presently undefined, indeterminable and uncharted area of potential rights and liabilities of landlords and tenants can serve only to vex them and to produce litigation otherwise avoidable." Id. at -, 293 N.E.2d at 852 (dissenting opinion). The same might have been said, of course, of the doctrine of constructive eviction, which predates the adoption of housing codes. But there is no reported evidence that the vagueness of the constructive eviction doctrine caused vexation and avoidable litigation.

61. In Green the court said that substantial compliance with codes would satisfy 
warranty doctrine in situations where there was no indication that the defective facilities were covered by any code provisions. ${ }^{62}$

In short, the housing codes should be viewed as a floor and not a ceiling. Threats to a tenant's health and safety, not simply or solely violations of the codes, should determine whether certain facilities are includable. Surely in most instances the housing codes will support this determination. But in some instances no statutory support will be available. In such cases the courts should nonetheless include under the implied warranty doctrine any facilities which, if defcctive, would threaten a tenant's health or safety.

\section{B. Seriousness of Defects Constituting a Breach}

Determining includable facilities is just one step. There remains the more difficult question of low serious a defect to that facility must be to constitute a breach of the warranty. Drawing once again on the housing code as a guide, some courts, including the Califormia Supreme Court in Green, have held that substantial compliance is sufficient and that minor violations may be considered de minimis. ${ }^{03}$ Others have indicated that the warranty requires defects serious enough to have constitued a constructive eviction if the tenant had vacated, ${ }^{64}$ a test which appears to differ only slightly, if at all, from one requiring

the doctrine only in "most" cases. 10 Cal. $3 \mathrm{~d}$ at 637,517 P.2d at 1183, 111 Cal. Rptr. at 719. See Morbeth Realty Corp. v. Velez, 73 Misc. 2d 996, 999-1000, 343 N.Y.S.2d 406, 410 (N.Y. City Civ. Ct. 1973).

62. See Academy Spires, Inc. v. Brown, 111 N.J. Super. 477, 482-83, 268 A.2d 556, 559 (Dist. Ct. 1970) (failure to supply heat, hot water, garbage disposal, or elevator service to a nine-story building; the opinion does not say whether codes covered these facilities, and it is doubtful that elevator service would have been required by any codes); Todd v. May, (1972-74 Transfer Binder) CCH Pov. L. ReP., II 17,949 (Conn. Cir. Ct. 1973) (failure to remove paint containing high degree of lead after having been duly warned by issuance of an order of the Dep't of Health); cf. Amanuensis, Ltd. v. Brown, 65 Misc. 2d 15, 17, 318 N.Y.S.2d 11, 14 (N.Y. City Civ. Ct. 1971) (failure to provide adequate security against criminal acts presented "substantial basis" for claim of breach of implied warranty; it is unclear whether codes covered security).

63. See, e.g., Javins v. First Nat'l Realty Corp., 428 F.2d 1071, 1082 n.63 (D.C. Cir.), cert. denied, 400 U.S. 925 (1970); Green v. Superior Court, 10 Cal. 3d 616, 637, 517 P.2d 1168, 1183, 111 Cal. Rptr. 704, 719 (1974); Hinson v. Delis, 26 Cal. App. 3d 62, 70, 102 Cal. Rptr. 661, 666 (1st Dist. 1972); Boston Housing Authority v. Hemingway, - Mass. -, -, 293 N.E.2d 831, 844 n.16 (1973) ("isolated" code violations will not constitute breach); King v. Moorehead, 495 S.W.2d 65, 74 (Mo. Ct. App. 1973).

64. In Academy Spires, Inc. v. Jones, 108 N.J. Super. 395, 403, 261 A.2d 413, 417 (L. Div. 1970), a lower court read a New Jersey Supreme Court case to stand for this proposition. In that case, Reste Realty Corp. v. Cooper, 53 N.J. 444, 251 A.2d 268 (1969), the court spoke of the two doctrines-implied warranty and constructive eviction-without carefully distinguishing them. The tenant, however, had vacated and thereby qualified under the constructive eviction doctrine. Accordingly, any discussion of the implied warranty doctrine was unnecessary. Thus relieved of the necessity to do so, the court in Academy Spires did not address this issue specifically. 
substantial compliance. ${ }^{65}$ But on the whole the courts have noticeably failed to provide much guidance. ${ }^{66}$ Certain general principles, lowever, seem to emerge from the cases. From the concern that the tenant be protected from threats to his safety or health, the courts appear to lave derived two concerns: that the tenant not be deprived of those essential functions which a residence is expected to provide; and that the tenant not be subjected to the fear of injury of a kind which, were the injury to occur, would impose tort liability on some responsible party. Many factors must be considered in resolving these concerns. Foremost among them are the effect of any defect on safety or sanitation $^{67}$ and the length of time such defects have persisted. ${ }^{68}$

Deprivation of essential residential functions is a theme, never fully articulated, which runs through many of the decisions. Courts lave apparently decided that certain elements of that "package of goods and services" 99 which constitutes the modern urban dwelling unit are vital. One must be able to sleep, to eat, to use a bathroom. If, in the eyes of a normal person, defects in the dwelling preclude stated:

65. In Reste Realty Corp. v. Cooper, 53 N.J. 444, 251 A.2d 268 (1969), the court

[A]uy act or omission of the landlord .... which renders the premises substantially unsuitable for the purpose for which they are leased, or which seriously interferes with the beneficial enjoyinent of the premises, .... constitutes a constructive eviction of the tenant.

Id. at 457, 251 A.2d at 274. See also Johnson v. Snyder, 99 Cal. App. 2d 86, 88, 221 P.2d 164, 166 (1st Dist. 1950).

66. There is quite general language, however, in some cases. Certain cases distinguish essential from nonessential facilities. E.g., Lund v. McArthur, 51 Hawaii 473, 476,462 P.2d 482, 484 (1969). Others concentrate on the amount of time the defect persists. E.g., Steinberg v. Carreras, 74 Misc. 2d 32, 37, 344 N.Y.S.2d 136, 143 (N.Y. City Civ. Ct. 1973). An often quoted passage (indeed, it was used by the court in Green) is this:

In a modern society one cannot be expected to live in a multi-storied apartment building without heat, hot water, garbage disposal or elevator service. Failure to supply such things is a breach of the imphed covenant of habitability. Malfunction of venetian blinds, water leaks, wall cracks, lack of painting, at least of the magnitude presented here, go to what may be called "amenities." Living with lack of painting, water leaks and defective venetian blinds may be unpleasant, aesthetically unsatisfying, but does not come within the category of uninhabitability.

Academy Spires, Inc. v. Brown, 111 N.J. Super. 477, 482-83, 268 A.2d 556, 559 (Dist. Ct. 1970). See also Hirent Realty Corp. v. McKay, $1 \mathrm{CCH}$ Pov. L. REP. $\{2105.60$ (N.Y. City Civ. Ct. 1970) (no breach where only evidence showed peeling paint and a leak in ceiling of common bathroom).

67. Mease v. Fox, 200 N.W.2d 791, 796-97 (Iowa 1972).

68. Id. See also Hinson v. Delis, 26 Cal. App. 3d 62, 70, 102 Cal. Rptr. 661, 666 (1st Dist. 1972); Boston Housing Authority v. Hemingway, - Mass. -, -, 293 N.E.2d 831, 843-44 (1973); King v. Moorehead, 495 S.W.2d 62, 76 (Mo. Ct. App. 1973).

69. Javins v. First Nat'l Realty Corp., 428 F.2d 1071, 1074 (D.C. Cir.), cert. denied, 400 U.S. 925 (1970), quoted in Green v. Superior Court, $10 \mathrm{Cal}$. 3d 616, 623, 517 P.2d 1168, 1172, 111 Cal. Rptr. 704, 708 (1974). 
the tenant from these essential functions, a breach of the warranty has occurred.

Deprivation, of course, can occur for any number of reasons. A bathroom may become useless due to the collapse of its ceiling ${ }^{70}$ or a hole in its floor caused by dry rot. ${ }^{71}$ Toilet facilities may fall into disrepair, ${ }^{72}$ cease to function, ${ }^{73}$ or simply not be present. ${ }^{74}$ Indeed, while use may still be possible for the desperate or insensitive, a bathroom may be so unpleasant ${ }^{75}$ or so burdensome of upkeep ${ }^{70}$ that in any real sense an ordinary person is deprived of its function.

Similarly, kitchen facilities can be in such disrepair as to constitute a breach of the warranty. ${ }^{77}$ Plumbing, of course-both for the supply of water, hot and cold, and for the disposal of waste and sewage-is as necessary to kitchens as to bathrooms. Any sustained disruption in this service goes beyond inconvenience to become a deprivation of essential residential functions. ${ }^{78}$ Despite some similarities, however, kitchen facilities differ in a quite sigmificant way from bathroom facilities. If they are faulty, stoves, ovens, and to a lesser degree refrigerators, freezers, and other electrical or gas appliances threaten not only deprivation, but physical harm as well. Such a dual threat to health and safety clearly is sufficiently serious to breach the warranty. ${ }^{79}$

Sleep is very special. Dwellings can and do exist without bathrooms or kitchens; that courts have included deprivation of these latier facilities under the implied warranty doctrine appears an accommodation to a modern perception of society. ${ }^{80}$ But if a dwelling does not

70. Green v. Superior Court, 10 Cal. 3d 616, 621, 517 P.2d 1168, 1170, 111 Cal. Rptr. 704, 706-07 (1974). 1972).

71. Hinson v. Delis, 26 Cal. App. 3d 62, 64, 102 Cal. Rptr. 661, 662 (1st Dist.

72. Pines v. Perssion, 14 Wis. $2 \mathrm{~d}$ 590, 593, 111 N.W.2d 409, 411 (1961).

73. Jackson v. Rivera, 65 Misc. $2 d$ 468, 471, 318 N.Y.S.2d 7, 10 (N.Y. City Civ. Ct. 1971).

74. Gillette v. Anderson, 4 IIl. App. 3d 838, 839, 282 N.E.2d 149, 150 (1972). 1972).

75. Hinson v. Delis, 26 Cal. App. 3d 62, 64, 102 Cal. Rptr. 661, 662 (1st Dist.

76. Marini v. Ireland, 56 N.J. 130, 134, 265 A.2d 526, 528 (1970). Marini purported to limit the tenant's remedy for breach of implied warranty to repair-aud-deduct or vacation of the premises, id. at 146, $265 \mathrm{A.2d}$ at 535, but the court rejected this limitation in Berzito v. Gambino, 63 N.J. 460, 468, 308 A.2d 17, 21 (1973).

77. Steele v. Latimer, 214 Kan. 329, —, 521 P.2d 304, 306 (1974); cases cited at notes 72-74 supra.

78. Green v. Superior Court, 10 Cal. 3d 616, 621, 517 P.2d 1168, 1170, 111 Cal. Rptr. 704, 706-07 (1974); Berzito v. Gambino, 63 N.J. 460, 463, 308 A.2d 17, 18-19 (1973).

79. See note 70 supra.

80. Notice that the court in Academy Spires, Inc. v. Brown included elevator service as an essential facility, no longer an amenity, for modern, multi-story apartment liv- 
at least provide sleep, what does it provide other than storage of personal belongings? Moreover, sleep is essential to health, and it can be disrupted not only by inadequate sleeping facilities theinselves, ${ }^{81}$ but also by encroachments upon sleep such as rat infestation ${ }^{82}$ or the fear that a wiring defect will lead to fire. ${ }^{83}$ Where sleep is deprived unnecessarily, even for relatively short periods, a breach of the warranty has occurred. ${ }^{84}$

Certain defects may affect several or all of these functions, causing deprivation. Thus drafts froin faulty doors ${ }^{85}$ or from broken or missing windows, ${ }^{86}$ or inadequate heating ${ }^{87}$ or ventilation ${ }^{88}$ can cause general deprivation of use, and as such constitute breaches of the warranty. More than this, however, these defects, especially an absence of heat, ${ }^{89}$ pose threats to health quite apart from depriving a tenant of certain vital residential functions.

Subjecting a tenant to the fear that he may suffer injury or deterioration in health due to an unrepaired defect is best viewed as an independent basis for breach of the warranty-although such fear can also be expressed in the deprivation of sleep. ${ }^{90}$ Inadequate heating ${ }^{91}$ and dangerous wiring, ${ }^{92}$ offer some illustration. It is not so much that stairs in disrepair make mobility inconvenient, that faulty wiring makes using certain kitchen appliances problematical, or that insufficient heat makes sleeping difficult that deprivation occurs. Rather it is that each threatens direct physical injury: faulty stairs or handrails collapse while people are using them; exposed or overloaded wiring causes fire; no heat in winter leads to colds, pneumonia, or worse, Thus, the principle that appears to have evolved is this: If the defect is such that tort hability would be imposed on the landlord were the harm

ing. Deprivation of this service, along with others, was held to be a breach of the warranty. 111 N.J. Super. 477, 482, 268 A.2d 556, 559 (Dist. Ct. 1970).

81. Cf. UNIFORM HousING CODE $\$ \S 503(\mathrm{~b})$, (c).

82. Green v. Superior Court, 10 Cal. 3d 616, 621, 517 P.2d 1168, 1170, 111 Cal. Rptr. 704, 706-07 (1974); Lemle v. Breeden, 51 Hawaii 426, 428, 462 P.2d 470, 472 (1969).

83. Lund v. McArthur, 51 Hawaii 473, 476, 462 P.2d 482, 484 (1969).

84. Lemle v. Breeden, 51 Hawaii 426, 428, 462 P.2d 470, 472 (1969).

85. Hinson v. Delis, 26 Cal. App. 3d 62, 64, 106 Cal. Rptr. 661, 662 (1st Dist. 1972); Steele v. Latimer, 214 Kan. 329, —, 521 P.2d 304, 306 (1974).

86. Berzito v. Gambino, 63 N.J. 460, 463, 308 A.2d 17, 18-19 (1973).

87. Id.; Green v. Superior Court, 10 Cal. 3d 616, 621, 517 P.2d 1168, 1170, 111

Cal. Rptr. 704, 706-07 (1974).

88. UNIFORM HOUSING CODE $\$ 701$ (c).

89. Steinberg v. Carreras, 74 Misc. 2d 32, 37, 344 N.Y.S.2d 36, 143 (N.Y. City

Civ. Ct. 1973).

90. See notes 80-84 supra and accompanying text.

91. See cases cited at notes 78,85 supra.

92. See cases cited at notes 70,83 supra. 
that is feared actually to occur, the defect constitutes a breach of the implied warranty of habitability despite the absence of injury.

\section{Other Factors in the Definition}

Having a sufficiently serious defect to an includable facility, however, does not end the inquiry, since, prumarily in dicta, several courts have indicated that certain other factors nay be relevant as well. Some courts, for instance, have stated that there can be no breach of the implied warranty if the defects were caused by the tenant's wrongful action or abnormal use of the premises, since it would be unfair to permit the tenant to benefit from his own wrong. ${ }^{03}$ Beyond this, the language of a few cases appears to state a flat rule that the tenant must give notice of the defects to the landlord in order later to clain a breach of the implied warranty.94 There would seem, however, to be no need for such notice where the landlord already knows of the defects. Several cases, therefore, have limited the notice requirement to defects not known to the landlord. ${ }^{95}$ Indeed, where defects exist in common areas under the landlord's control, even the landlord's lack of actual knowledge of these defects should not excuse him, since he has a duty to inspect those areas. ${ }^{06}$ Some cases which impose a notice

93. Javins v. First National Realty Corp., 428 F.2d 1071, 1082 n.62 (D.C. Cir.), cert. denied, 400 U.S. 925 (1970); Hinson v. Delis, 26 Cal. App. 3d 62, 70, 102 Cal. Rptr. 661, 666 (1st Dist. 1972); Mease v. Fox, 200 N.W.2d 791, 796-97 (Iowa 1972); Boston Housing Authority v. Hemingway, - Mass. -, -, 293 N.E.2d 831, 843-44 (1973); King v. Moorehead, 495 S.W.2d 65, 76 (Mo. Ct. App. 1973); Kline v. Burns, 111 N.H. 87, 93, 276 A.2d 248, 252 (1971); Marini. v. Ireland, 56 N.J. 130, 144, 265 A.2d 526, 534 (1970).

94. Hinson v. Delis, 26 Cal. App. 3d 62, 70, 102 Cal. Rptr. 661, 666 (1st Dist. 1972); Berzito v. Gambino, 63 N.J. 460, 469, 308 A.2d 17, 22 (1973); Marini v. Ireland, 56 N.J. 130, 146, 265 A.2d 526, 535 (1970) (if tenant is unable to give notice after reasonable attempt to do so, he may use repair-and-deduct remedy).

95. Mease v. Fox, 200 N.W.2d 791, 797 (Iowa 1972); King v. Moorehead, 495 S.W.2d 65, 76 (Mo. Ct. App. 1973); Academy Spires, Inc. v. Brown, 111 N.J. Super. 477, 483, 268 A.2d 556, 560 (Dist. Ct. 1970). See also Boston Housing Authority v. Hemingway, - Mass. - , - 593 N.E.2d 831, 844 n.17 (1973) (where one tenant gives notice of defects affecting habitability of other tenants' apartments, such other tenants may rely on the notice). There is authority that a landlord may be prosecuted for known serious defects, even though he received no official notice of them. District of Columbia v. First Nat'1 Realty Corp., 1 CCH Pov. L. REP. \ 2235.68 (D.C. Ct. Gen. Sess., 1969). Practice note: It would be good practice, of course, for the tenant to give such notice in writing and keep a copy, to facilitate proof of the landlord's knowledge of all defects. A form notice appears in M. Moskovitz, R. WARnER \& C. SHERMan, CALIForna TENANTS' HaNdBook 96 (1972).

96. Cf. Rodenberger v. Frederickson, 111 Cal. App. 2d 139, 141, 244 P.2d 107, 108 (1st Dist. 1952); Rathbun Co. v. Simmons, 90 Cal. App. 692, 698, 266 P. 369,372 (3d Dist. 1928). See also UNIForM Housing CODE \$ 201(c) ("Every owner . . . shall be responsible for keeping that part of the building or premises which he occupies or controls in a clean, sanitary, and safe condition mcluding the shared or public areas in a building containing two or more dwelling units."). 
requirement also state that the landlord must be given reasonable time to make the repairs. ${ }^{97}$

Thus if one considers, along with the above discussion of what constitutes a sufficiently serious defect, the requirements that the tenant not be at fault in the defect's causation, that he give the landlord notice, and that he allow reasonable time for repair, a new definition emerges of what constitutes breach. Depriving a tenant of an essential residential function or subjecting him to fear of injury or deterioration in health, when caused by a defect in the dwelling, is a potential breach of the implied warranty so long as the tenant is not at fault for the defect's existence. The deprivation or subjection becomes an actual breach once the landlord has been notified or otherwise has actual or constructive knowledge of the defect and has had reasonable time to repair. ${ }^{98}$

97. Hinson v. Delis, 26 Cal. App. 3d 62, 70, 102 Cal. Rptr. 661, 666 (1st Dist. 1972); King v. Moorehead, 495 S.W.2d 65, 76 (Mo. Ct. App. 1973); Berzito v. Gambino, 63 N.J. 460, 469, 308 A.2d 17, 22 (1973).

One court which considered both these factors generally relevant, however, notcd that they should not be considered where the defects are present at the beginning of the tenancy and the tenant decides to rescind immediately, "because the landlord is obligated to deliver the premises in a condition fit for immediate occupation." Boston Housing Authority v. Hemingway, -Mass. -, 一, 293 N.E.2d 831, 844 n.18 (1973). See also Lemle v. Breeden, 51 Hawaii 426, 427, 462 P.2d 470, 476 (1969), where the court spoke of a "reasonable time" requirement but allowed the tenant to vacate after only three days in a rat-infested house.

98. Some additional factors are worthy of note. One case, for instance, considered the nature of the landlord's efforts to remedy the defects, and found a breach of warranty partly because these efforts "were feeble and tardy, and then only made when prodded by the court and municipal authorities." Berzito v. Gambino, 114 N.J. Super. 124, 128, 274 A.2d 865, 867 (Dist. Ct. 1971), affd, 63 N.J. 460, 308 A.2d 17 (1973). Other cases have indicated that the age of the building should be considered in determining whether the warranty has been breached. Mease v. Fox, 200 N.W.2d 791, 796-97 (Iowa 1972); King v. Moorehead, 495 S.W.2d 65, 76 (Mo. Ct. App. 1973); Kline v. Burns, 111 N.H. 87, 93, 276 A.2d 248, 252 (1971). It has not been explained, however, why this should be relevant. Moreover, this factor could be analyzed in either of two ways; on the one hand, an older building is more likely to be defective, and therefore the tenant in such a building must expect to tolerate more defects; on the other hand, this very expectation should cause the landlord to be more diligent in preventing and repairing the expected defects. The first construction is not consistent with the purposes of the implied warranty doctrine in that it weakens the doctrine's assistance to code enforcement where it could be most helpful. Moreover, it nay enable landlords to take advantage of tenants in the weakest bargaining position. The latter construction is inore consistent with the purposes of the implied warranty doctrine, and it is supported by one decision expressly holding the landlord responsible for "deterioration from age." Marini v. Ireland, 56 N.J. 130, 146, 265 A.2d 526, 534 (1970).

Still other cases have held that the amount of rent should be considered. Mease v. Fox, 200 N.W.2d 791, 796-97 (Iowa 1972); Kline v. Burns, 111 N.H. 87, 93, 276 A.2d 248, 252 (1970); Marini v. Ireland, 56 N.J. 130, 146, 265 A.2d 526, 534 (1970). Again, this has not been explained. If meant to imply that a tenant paying a low rent must expect to put up with poorer conditions than a tenant who pays more, this factor is inconsistent with the purpose of the implied warranty doctrine of protecting the low- 


\title{
Reasonable Rent and General Damages
}

\author{
Determining reasonable rent is probably the most troublesome \\ of all the difficult issues raised by the implied warranty doctrine.
}

income tenant from his own lack of bargaining power. If meant to imply that a landlord receiving a lower rent cannot afford so well to make repairs, it is inconsistent with the purpose of assisting in the enforcement of the housing codes. Moreover, consideration of the amount of rent might, in effect, permit the landlord to bargain away his obligation to repair, which one court has expressly forbidden. Foisy v. Wyman, 83 Wash. 2d 22, 一, 515 P.2d 160, 164-65 (1973). There appears no good reason why the amount of rent should be a relevant factor.

Practice note-evidence of the breach: Where the tenant alleges certain code violations constituting the breach, the housing code itself should be introduced into evidence. In most California cases, this will be the Uniform Housing Code, see note 41 supra, which applies throughout the state except where standards at least as strict have been adopted by cities or counties. Cal. Health \& SAFETX Code \& 17951 (West Supp. 1974). Most cities and counties, however, have simply incorporated the Code by ordinance. A copy of the Code should be certified as a true copy by the city or county clerk before it is introduced. See CAL. Evid. CoDe $\$ 1530$ (a)(2) (West 1973).

The Court is required to take judicial notice of the Code as incorporated in the State Housing Law. See Cad. Evid. Code $\$ 451$ (b) (West, 1973). See also California EVIDENCE BENCHBOOK $\$ 47.2$, at 834 (1972). It is permitted to take judicial notice of the Code where it is incorporated by local ordinance. See CaL. Evid. Code $\$ 452$ (b) (West 1973); see also CALIFORNIA EvIDENCE BENCHBOoK $\$ 47.3$, at 837 (1972). The tenant's attorney, however, should introduce it into evidence in any case to facilitate the court's determination of whether code violations occurred.

Usually the best way to prove that conditions existed on the premises which violated the code is through evidence of an inspection by a city or county code enforcement official. (Several cases have held that the code official's finding of code violations is not required to sustain a finding of breach of implied warranty. See Javins v. First Nat'1 Realty Corp., 428 F.2d 1071, 1082 n.62 (D.C. Cir.), cert. denied, 400 U.S. 925 (1970); Diamond Housing Corp. v. Robinson, 257 A.2d 492, 494 (D.C. Ct. App. 1969); Reese v. Diamond Housing Corporation, 259 A.2d 112 (D.C. Ct. App. 1969); Foisy v. Wyman, 83 Wash. 2d 22, -, 515 P.2d 160, 166 n.1 (1973). Such a finding does, however, constitute evidence of the breach. Boston Housing Authority v. Hemingway, Mass. -, -, 293 N.E.2d 831, 843 n.15 (1973).) Records of such an inspection, since they are public, can be discovered and copied simply by visiting the official's office. CAL. Gov'r CODE $\$ \S 6253,6254.7$ (c) (West 1973). These records may be introduced despite their hearsay nature, as they are official records. See CAL. EvID. CODE $\$ 1280$ (West 1973). See also Cal Ifornia Evidence Benchbook \& 5.1, at 95 (1972). They may be authenticated through the testimony of the official himself, see CAL. EVID. CODE $\$ \$ 1400-01$ (West 1973), although such authentication may be unnecessary if copies of the records are certified by the official as a true copy and the court is willing to take judicial notice of the official's position and the genuinness of his signature. Cf. Cal. EVID. CODE $\$ \S 1280,1530$ (West 1973); CaLIfornia EVIDENCE Benchbook $\$ \S 5.2,31.5$, at 96,563 (1972).

If the code official himself will make a good witness for the tenant, he should be served with a subpoena to testify and a subpoena duces tecum to bring his records to the trial. See Cal. Code Ctv. Pro. $\$ 1985$ (West 1973). The testimony of people (including the tenant) who saw the defective conditions may also be used to prove the code violations, of course. Through them, photographs may be introduced which confirm their testimony. See CAL. Evm. CODE $\$ \S 250,1400-01$ (West 1973); see also CaLIFon- 
While courts agree that the tenant who proves a breach nonetheless owes reasonable rent for the period of the breach, ${ }^{99}$ they are unclear and at odds as to how this amount should be determined. Two basic premises, however, do emerge from the cases. First, it appears that the question of reasonable rent is to be viewed as one aspect of the question of the tenant's general damages from breach of the warranty. ${ }^{100}$ That is, reasonable rent is to be calculated by subtracting from the contract rent withheld the amount of provable general damages suffered by the tenant. Second, the cases agree that the tenant is not to be demed damages just because they are difficult to determine precisely. The damages, after all, were caused by the landlord's wrongful conduct. Furthermore, damages equally difficult to

NIA EVIDENCE BENCHBOoK $\S 30.5$, at 546 (1972). These witnesses might also testify regarding the other factors bearing on whether there was a breach of warranty, such as the effect of the defects on the tenant's health and safety, the length of time they persisted, whether they were caused by the tenant's abnornal use, and whether the landlord had notice of the defects and a reasonable time to repair them.

If there were a code enforcement official's record of the violations, this might be used to prove the landlord's knowledge of the defects, since the official undoubtedly inforned the landlord of the results of his inspection. Boston Housing Authority v. Hemingway, - Mass. -, -, 293 N.E.2d 831, 843 n.15 (1973). As discussed earlier, however, some cases indicate that the tenant must give the landlord notice of the defects. Until that issue is resolved, it would be wise for the tenant to give a dated written notice of the defects and keep a copy for introduction at trial. See M. MosKovitz, R. WARNer \& C. Sherman, California Tenants' Handboox 72, 76 (1972).

Finally, one of the most effective ways to impress the factfinder as to the existence aud seriousness of the defects is a personal visit to the premises by the judge or jury (assuming that the defects still exist at time of trial). In one New York case, after the court heard the tenant describe conditions constituting "a chamber of horrors," the judge personally visited the premises. He then reported that "[t]he verbal description of the conditions on the record was not sufficient to prepare me for what my eyes now saw." He ordered all unpaid rents to be abated and entered judgment for the tenant. Mannie Joseph, Inc. v. Stewart, 71 Misc. 2d 160, 161, 335 N.Y.S.2d 709, 710 (N.Y. City Civ. Ct. 1972). In California, the judge has discretion to visist the premises himself. Cf. Union Oil Co. v. Reconstruction Oil Co., 20 Cal. App. 2d 170, 182, 66 P.2d 1215, 1220 (4th Dist. 1937); see also B. WITKIN, CALIFORNIA EVIDENCE, \$§ 643-45 (1966). He may also have the jury conducted to the preinises. CAL. CODE Crv. PRo. \$ 610 (West 1973). See also B. WITKIN, CaliforNIA EVIDENCE $\S$ 643-45 (1966).

99. Javins v. First Nat'l Realty Corp., 428 F.2d 1071, 1082-83 (D.C. Cir.), cert. denied, 400 U.S. 925 (1970); Green v. Superior Court, 10 Cal. 3d 616, 629, 517 P.2d 1168, 1177, 111 Cal. Rptr. 704, 712 (1974); Hinson v. Delis, 26 Cal. App. 3d 62, 70, 102 Cal. Rptr. 661, 666 (1st Dist. 1972); Pines v. Perssion, 14 Wis. 2d 590, 597, 111 N.W.2d 409, 413 (1961); cf. Seely v. White Motor Co., 63 Cal. 2d 9, 14-15, 403 P.2d 145, 149, 45 Cal. Rptr. 17, 21 (1965). See also Reste Realty Corp. v. Cooper, 53 N.J. 444, 462 n.1, 251 A.2d 268, 277 n.1 (1969).

100. After the court in Green set out the reasonable rent requirement, $10 \mathrm{Cal} .3 \mathrm{~d}$ at 629,517 P.2d at 1177,111 Car. Rptr. at 712 , it went on to discuss it in terms of damages. Id. at 638-39, 517 P.2d at 1183-84, 111 Cal. Rptr. at 719-20. See also Kline v. Burns, 111 N.H. 87, 93, 276 A.2d 248, 252 (1971) (tenant may obtain relief from landlord's breach "by offsetting his damages against a claim made against him by the landlord"). 
compute with any certainty are allowed in other contract and tort cases. $^{101}$

\section{A. Two Suggested Approaches: Difference in Value and Percentage Reduction in Use}

The cases have produced two approaches for determiming the amount of general damages caused by the breach: difference in value and percentage reduction of use. Under the difference in value approach, the "tenant's damages shall be measured by the difference between the fair rental value of the premises if they had been as warranted and the fair rental value of the premises as they were during occupancy by the tenant in the unsafe and unsamitary condition."102 Under this test the contract rent the tenant agreed to pay is irrelevant, except perhaps as evidence of the fair rental value of the premises. ${ }^{103}$

101. Green v. Superior Court, 10 Cal. 3d 616, 638-39, 517 P.2d 1168, 1183, 111 Cal. Rptr. 704, 719 (1974); see Academy Spires, Inc. v. Brown, 111 N.J. Super. 477, 485-87, 268 A.2d 556, 561-62 (Dist. Ct. 1970).

102. Mease v. Fox, 200 N.W.2d 791, 797 (Jowa 1972), quoted in Green v. Superior Court, 10 Cal. 3d 616, 638, 517 P.2d 1168, 1183, 111 Cal. Rptr. 704, 719 (1974); accord, Boston Housing Authority v. Hemingway, - Mass. -, -, 293 N.E.2d 831, 845 (1973); see 11 S. Williston, Contracts \$ 1404, at 563 (3d ed. 1968); cf. Cal. COMM'L CODE $\$ 2714(2)$ (West 1974), based on UNIFORM CoMmercinL CODE $\$ 2$ 714. See also 84 HARv. L. REv. 729, 736 (1971). Thus, if the rental value of the premises in their defective condition were $\$ 100$, and they would have been worth $\$ 150$ if not defective, the tenant has sustained general damages of $\$ 50$ per month.

103. Suppose the contract rent is $\$ 150$ per month. If thcre were no apparent defects on the premises when the tenant moved in, the agreement to rent for $\$ 150$ is evidence that the fair market rental value of the premises "as warranted" was $\$ 150$, since that is what a willing landlord and tenant agreed to pay for such premises on the open market. (Conversely, if the defects were known to the tenant at the timc he agreed to the contract rent, then that rental figure would be evidence of the market rental value of the premises in their defective condition.) But this is only one item of evidence, and the tenant should be free to show that he got a "bargain" and the premises really had a market value of $\$ 175$. Cf. Mease v. Fox, 200 N.W.2d 791, 797 (Iowa 1972). See also King v. Moorehead, 495 S.W.2d 65, 76 (Mo. Ct. App. 1973). If the value of the premises in their defective condition was determined to be $\$ 100$, then the tenant's damages were $\$ 75$, rather than $\$ 50$.

Should this same analysis operate where the landlord got the bargain, i.e., where the market value of the premises in their condition when rented was only $\$ 130$ (although the tenant agreed to pay \$150)? The problem with requiring a reduction of damages to allow for the landlord's good bargaining is that it penalizes the tenant whom the implied warranty doctrine was designed to protect. The tenant who bargains poorly - the one most in need of the protection of the implied warranty-would get the least protection from the doctrine. He not only must pay more for the premises than they are worth in proper condition, he would have to put up with serious defects which later develop without being able to claim damages (although he still should be able to withhold his rent until the amount of damages is determined, if there was a breach). But cf. Ohsaki v. Ahern, 85 Cal. App. 199, 200, 259 P. 97 (1st Dist. 1927) ("If defendant wanted to keep the benefit of his bargain [claimed here as an offset against tenant's damages], he should have performed his part of it.").

A solution to this problem might be to allow the tenant the benefits of his good 
This difference in value approach presents difficult problems on two levels. First, proving the two relevant inarket values is at best difficult and expensive, at worst impossible, at least if calculations of any accuracy are required. While one of the two values might be inferred from the contract rent, ${ }^{104}$ the other depends upon the expert testimony of appraisers. Determining the market value of defective premises requires answering the hypothetical question of how much rent a willing landlord and willing tenant would agree upon for the premises with those particular defects. A competent answer would seem to require a survey by an expert of similar properties in the area. Indeed, even such a sophisticated probe of market value may have dubious worth. ${ }^{105}$

bargaining, but set general damages at a minimum of the difference between the rental value of the defective premises aud the contract rent. This difference has been proposed as the test of damages by some courts, although they have failed to recognize that it would deprive the good bargaining tenant the benefit of his bargain if it were applied to him. See King v. Moorehead, 495 S.W.2d 65, 76 (Mo. Ct. App. 1973); Kline v. Burns, 111 N.H. 87, 93-94, 276 A.2d 248, 252 (1971); Academy Spires, Inc. v. Brown, 111 N.J. Super. 477, 485, 268 A.2d 556, 561 (Dist. Ct. 1970); Glyco v. Schultz, 35 Ohio Misc. 25, 34, 289 N.E.2d 919, 926 (Sylvania Mun. Ct. 1972). These courts might lave mistakenly copied the method of measuring the value of the unexpired part of a leaselold which a tenant loses by condemnation or constructive eviction. Since the leasehold lias economic value only if the projected market rental value exceeds the contract reut, that method of measuring is specifically designed to give the ousted tenant the benefit of his bargain. In breach of warranty cases, lowever, the tenant is damaged not by his future loss of the leaseliold, but by a deficiency in quality of the leasehold, since he is remaining in possession. Compare CAL. COMM² CODE $\& 2713$ (West 1964) (damages-goods not received) with CAL. COMM'L CODE $\S 2714$ (West 1964) (damages -goods received, but defective).

The resulting rule, then, would read something like this: the tenant's damages shall be measured by the difference betweeu the fair reutal value of the premises as they were during occupancy by the tenant in the unsafe and unsanitary condition and the higher of the following two figures: (1) the fair rental value of the premises if they had been as warranted, and (2) the contract rent.

This issue may be largely academic, because the difficulty and expense of proving the two relevant market values will probably make the "difference in value" approach virtually useless. While one of the two values might be inferred from the contract rent, the other can be proved (if at all) only by the expert testimony of someone knowledgeable about appraisal techniques. For example, if the contract rent is $\$ 150$ and the defects occurred after the premises were rented, $\$ 150$ might be assumed to be the market value of the premises "as warranted", but the market value of the premises with the defects will require answering the lypothetical question: low much rent would a willing landlord and willing tenant agree upon for the premises with those particular defects. A competent answer would seem to require a survey of "similar" properties in the area by someone who knows what to look for. While such a survey might be difficult to perform in a way that casts much light on the true market rental value of the premises in litigation, it would appear to be at least an essential starting point for an "educated guess."

104. See note 103 supra.

105. In Steinberg v. Carreras, 74 Misc. $2 d$ 32, 38, 344 N.Y.S.2d 136, 144 (N.Y. City Civ. Ct. 1973), the trial judge noted: "I seriously doubt that statistical information about the value of apartments operated in violation of law is avilable in a form that perinits meaningful expert testimony." And in Academy Spires, Inc. v. Brown, 111 N.J. 
There is, however, a second problem with this approach: its high cost makes it generally unusable in the ordinary implied warranty dispute, since the amount of rent withheld in such cases seldom goes as high as $\$ 1000$. Moreover, even where the amount in dispute theoretically makes such an investment worthwhile, this approach as a practical matter is unavailable for low- and moderate-income tenants who simply cannot afford high litigation costs. ${ }^{106}$ As one court expressed it: "The economic realities of proceedings involving residential tenants make it unlikely that such testimony would be readily available to tenants in the usual case."107 If the tenant were required to furnish costly evidence, the relief intended to be afforded to the tenant by the implied warranty doctrine would be substantially diminished. ${ }^{108}$ Apparently for these reasons, none of the several cases which purport to endorse the difference in value approach has actually applied it. ${ }^{100}$

Rejecting the difference in value approach as too problem-bound, a New Jersey court, in Academy Spires, Inc. v. Brown, ${ }^{110}$ adopted a new approach-percentage reduction of use. The Green opinion appears to endorse this alternative approach. ${ }^{111}$ But while Green's cita-

Super. 477, 486, 268 A.2d 556, 562 (Dist. Ct. 1970), the judge said: "I am dubious that use of expert testimony could add to either accuracy or certainty."

The problems involved here are probably similar to some of those involved in appraising the value of leasehold interests in eminent domain cases. See, e.g., Horgan \& Edgar, Leasehold Valuation Problem in Eminent Domain, 4 U.S.F.L. REv. 1 (1969).

106. Note that fees for expert witnesses are not recoverable as costs. CAL. Gov'T CODE $\$ 68092.5$ (West Supp. 1974).

107. Steinberg v. Carreras, 74 Misc. 2d 32, 38, 344 N.Y.S.2d 136, 144 (N.Y. City Civ. Ct. 1973).

108. Academy Spires, Inc. v. Brown, 111 N.J. Super. 477, 486, 268 A.2d 556, 562 (Dist. Ct. 1970).

109. See, e.g., Glyco v. Schultz, 35 Ohio Misc. 25, 34, 289 N.E.2d 919, 926 (Sylvania Mun. Ct. 1972), where the court said it would follow the "difference in value" approach and then found that the value of the premises "was diminished by $2 / 3$ based on the uncontradicted testimony of [the tenants] that substantial violations of the Lucas County Housing Code existed at the premises." The court did not even pretend to base its "finding" of two-thirds diminution on any evidence of a difference in market value; it seems to have been a gut reaction.

110. 111 N.J. Super. 477, 268 A.2d 556 (Dist. Ct. 1970).

111. Green v. Superior Court, 10 Cal. 3d 616, 639 n.24, 517 P.2d 1168, 1183 n.24, 111 Cal. Rptr. 704, 719-20 n.24 (1974). While the court in Academy Spires failed to discuss the "percentage dimunition" approach in any detail, it is interesting to see how the court in Green characterized the case:

The case of Academy Spires, Inc. v. Brown [citation omitted] demonstrates one reasonable response to the problem. The Academy Spires court, after fully acknowledging the difficulty of precisely determining damages resulting from a landlord's breach of an implied warranty of habitability, assessed damages by a "percentage reduction of use" approach, under which the court reduced the tenant's rental obligation by a percentage corresponding to the relative reduction of use of the leased premises caused by the landlord's breach. In applying this approach, the Academy Spires court carefully reviewed both the importance of the particular defects in the premises (including failure to supply heat, hot water, elevator service and a working incinerator) and the length of 
tion to Academy Spires might lead one to believe that the New Jersey court, in adopting percentage reduction of use, engaged in a careful review of the evidence, resulting in an objective estimate that the tenant's ability to use the premises was reduced by the figure of 25 percent, a careful reading of Academy Spires fails to show that such an objective computation was even attempted. While the court did review the seriousness of the defects, it did not attribute percentages of reduction in use to each defect. Moreover, it did not consider the percentage of time the tenant was able or unable to use certain parts of the premises, the percentage of floor space affected by the defective facilities, or other similar factors affecting percentage reduction of use. ${ }^{112}$

Indeed, it is highly questionable whether the percentage reduction of use approach can ever result in a figure which is objectively justifiable, even as an estimate. Any real attempt to prove percentage reduction in use must consider the time and floor space affected by the defects, assuming this data is available from the tenant. But this is only the beginning, for some weight inust be attributed to each affected facility. If there is no hot water in the bathroom, the tenant cannot use the bath, but he can use the sink some of the time and the toilet all the time. Also, he may use the toilet inore than the sink, the sink more than the bath-all of which, it would seem, is crucial to determining the percentage reduction in use of the bathroom. Moreover, after this is decided, it nnust be determined how much this reduces the use of the premises as a whole. Should this be done according to the percentage of floor space taken up by the bathroom, even if the tenant uses the bathroom more than other parts of the premises? (Is a storeroom or closet in use even when the tenant is not there but his belongings are?) And this process must be repeated for each defect.

The problems with this analysis are obvious. The questions posed seein unanswerable if viewed as calling for objectively verifiable answers. Even if answerable, they would appear to require expert testimony, the cost of which is often prohibitive, at least for the low-income tenant. In the reported cases, therefore, the percentage reduction of use approach has been applied in inuch the same way as the difference in value approach: it has been talked about, but never actually used.

time such defects had existed (from one or two days to several weeks), and finally concluded that under all the circumstances "the diminution of rent of Id. $25 \%$ is a fair amount."

112. See Academy Spires, Inc. v. Brown, 111 N.J. Super. 477, 487-88, 268 A.2d 556, 562 (Dist. Ct. 1970). 
Indeed, of the several reported cases which have actually lowered the rent to a reasonable rent after finding a breach of the implied warranty, not one contains an articulated analysis for computing the final figure. ${ }^{113}$ It may well be, of course, that the courts did not intend that either of the two suggested approaches be applied literally, but only considered as relevant factors which might in a particular case assist the court in arriving at a viscerally fair damage amount. This possibility is supported by the fact that several of the implied warranty cases lave favored, in some circumstances, abating the entire rent ${ }^{114}$-an impossible result under a literal application of either the difference in value of percentage reduction in use approach, since even the worst hovel lias some market value and has had some use if the tenant has lived there.

Treating either of the approaches as factors to consider-as guides to the court in its exercise of discretion-rather than as literal tests may resolve one problem. It would diminish the need for expert testimony, and thus enhance the usefulness of either approach to the low-income tenant. This treatment, however, does not resolve the major theoretical problein with either test: that each appears grounded in a conception of the tenant as some kind of commercial individual concerned about the economic disadvantage of a defective building. The residential tenant does not view his residence, it would seem, as a building to be, say, sublet at a profit, or as a warehouse under a contract providing a minimal floor space for the storage of goods. Defects to commercial buildings in such contexts are perhaps properly viewed as creating purely financial losses measureable by market value or reduced use. The residential tenant, lowever, is damaged in a quite different way. A new proposal, made immediately below, reflects inore realistically the actual damage suffered by the residential tenant.

\section{B. A New Proposal: Discomfort and Annoyance}

Generally, the residential tenant who has suffered a breach of the

113. See id.; Samuelson v. Quinones, 119 N.J. Super. 338, 343, 291 A.2d 580, 583 (Super. Ct. App. Div. 1972); Berzito v. Gambino, 114 N.J. Super. 124, 126-27, 274 A.2d 865, 866 (Dist. Ct. 1971), aff'd, 63 N.J. 460, 308 A.2d 17 (1973); Steinberg v. Carreras, 74 Misc. 2d 32, 38, 344 N.Y.S.2d 136, 144 (N.Y. City Civ. Ct. 1973); Morbeth Realty Corp. v. Rosenshine, 67 Misc. 2d 325, 327, 323 N.Y.S.2d 363, 366 (N.Y. City Civ. Ct. 1971); Glyco v. Schultz, 35 Ohio Misc. 25, 34, 289 N.E.2d 919, 926 (Sylvania Mun. Ct. 1972).

114. Bell v. Tsintolas Realty Co., 430 F.2d 474, 485 (D.C. Cir. 1970); Javins v. First Nat'l Realty Corp., 428 F.2d 1071, 1083 (D.C. Cir.), cert. denied, 400 U.S. 925 (1970); Green v. Superior Court, 10 Cal. 3d 616, 639, 517 P.2d 1168, 1183, 111 Cal. Rptr. 704, 720 (1974); Mannie Joseph, Inc. v. Stewart, 71 Misc. 2d 160, 162, 335 N.Y.S. 2d 709, 711 (N.Y. Civ. Ct. 1972); Amanuensis, Ltd. v. Brown, 65 Misc. 2d 15, 21-22, 318 N.Y.S.2d 11, 19 (N.Y. Civ. Ct. 1971); Foisy v. Wyman, 83 Wash. 2d 22, -, 515 P.2d 160, 168 (1973). 
warranty does not lose money. He instead cannot bathe as frequently as he would like or at all if there is inadequate hot water; he must worry about rodents harassing his children or spreading disease if the premises are infested; or he must avoid certain rooms or worry about catching a cold if there is imadequate weather protection or heat. Thus discomfort and annoyance are the common injuries caused by each breach and hence the true nature of the general damages the tenant is claiming.

While it is somewhat unusual to allow compensation for such injuries in an action for breach of contract, it should be allowed here. First, damages for discomfort and annoyance have been allowed where the breach of contract is also a nuisance, ${ }^{115}$ as it often appears to be here. ${ }^{118}$ Second, the implied warranty theory is essentially a tortcontract hybrid concept, ${ }^{117}$ a concept which has been used to justify, in the sales of goods, damages for mental suffering caused by the breach of an implied warranty of fitness for the purpose intended.118 Finally, damages for a very similar injury-mental suffering-have been allowed in a breach of contract action where the subject of the contract directly concerned the comfort of the aggrieved party. ${ }^{119}$

Another advantage of the discomfort and annoyance approach is that the tenant could in many cases prove his general damages by the same evidence used to prove the seriousness of the defects-their effect on safety and sanitation ${ }^{120}$ and the length of time they persisted. ${ }^{121}$

Nor need precedent be wholly abandoned in order to adopt this suggested new approach. Although reduction in use does seem logically more suited to the commercial rather than the residential tenant, certainly the tenant's ability to use the facilities of the premises

115. As the California Supreme Court put it:

It is settled that, regardless of whether the occupant of land has sustained physical injury, he may recover damages for the discomfort and annoyance of himself and the members of his family and for mental suffering occasioned by fear for the safety of himself and his family when such discomfort or suffering has been proximately caused by a trespass or a nnisance.

Acadia, California, Ltd. v. Herbert, 54 Cal. 2d 328, 337, 353 P.2d 294, 299, 5 Cal. Rptr. 686, 691 (1960) (emphasis added). Cf. Crisci v. Security Ins. Co., 66 Cal. 2d 425, 433-34, 426 P.2d 173, 179, 58 Cal. Rptr. 13, 19 (1967). See also Herzog v. Grosso, 41 Cal. 2d 219, 225, 259 P.2d 429, 433 (1953); Judson v. L.A. Suburban Gas Co., 157 Cal. 168, 171-72, 106 P. 581, 582 (1910); Sturges v. Charles L. Harney, Inc., 165 Cal. App. 2d 306, 323, 331 P.2d 1072, 1082 (1st Dist. 1958).

116. See generally notes 193-202 infra and accompanying text.

117. Sce note 200 infra.

118. Klein v. Duchess Sandwich Co., 14 Cal. 2d 272, 93 P.2d 799 (1939).

119. Windeler v. Scheers Jewelers, 8 Cal. App. $3 \mathrm{~d}$ 844, 88 Cal. Rptr. 39 (1st Dist. $1970)$.

120. See note 67 supra.

121. See note 68 supra. 
has a direct bearing on how much discomfort and inconvenience has been suffered. Therefore, any evidence of percentage reduction in use is relevant to the ultimate determination. Evidence of difference in value, however, seeins out of place. Market value has no bearing on the actual physical discomfort and annoyance caused by the breach. Moreover, it is highly unlikely that the tenant is emotionally or even financially concerned about any drop in the market value of the premises. The typical residential tenant rents his dwelling not for monetary gain, but to live in. Evidence of difference in value, therefore, lias little or no probative value in determining actual damage, and should accordingly be discounted or discarded altogether as a determinant of tenant imjury.

Placing a dollar value on the injury caused in a given case by a tenant's discomfort and annoyance is admittedly quite difficult. This difficulty is not, lowever, sufficient reason to disallow such damages. Fact-finders face a similar problem every day where damages for pain and suffering are claimed in personal imjury trials. The law recognizes the difficulty involved liere, but trusts the good judgment of the factfinder to set damages for pain and suffering in a reasonable amount. ${ }^{122}$

Using the discomfort and annoyance approach, a court could assess damages at an amount equaling-or even exceeding-the contract rent, ${ }^{123}$ and thus reduce the reasonable rent to zero. This should not

122. Professor McCormick wrote:

Translating pain and anguish into dollars can, at best, be only an arbitrary allowance, and not a process of measurement, and consequently the judge can, in his instructions, give the jury no standard to go by; he can only tell them to allow such amount as in their discretion they may consider reasonable. . . . The chief reliance for reaching reasonable results in atteinpting to value suffering in terns of money must be the restraint and common sense of the jury. - .

C. MCCormick, Damages $\$ 88$, at 318-19 (1935), quoted in Beagle v. Vasold, 65 Cal. 2d 166, 172, 417 P.2d 673, 675, 53 Cal. Rptr. 129, 131 (1966). See also CaIrfornin JURY INSTRUCTIONS, CIVII (BAJI) $\$ \$ 14.00,14.13$ (5th ed. 1969). Of course, no expert testimony is required to support an award for pain and suffering. See Beagle v. Vasold, 65 Cal. 2d 166, 172, 417 P.2d 673, 675, 53 Cal. Rptr. 129, 131 (1966).

123. Practice note-damages. A key determinant of the amount of damages awarded for discomfort and annoyance may well be the power of persuasion of the tenant's attorney in final argument. He might argue, for exaunple, that the tenant should be compensated at least $\$ 5$ per day where his family lived in heatless premises for the inonth of January. Such "per diem" arguments were approved in Beagle v. Vasold, 65 Cal. 2d 166, 417 P.2d 673, 53 Cal. Rptr. 129 (1966). If this argument is accepted and the contract rent did not exceed $\$ 155$, this would lower the reasonable rent to zero.

If the general damages exceed the contract rent-as they well might in serious cases -the tenant will liave to seek the excess in an independent action, because the law currently does not permit the tenant to counterclain in unlawful detainer cases. Knowles v. Robinson, 60 Cal. 2d 620, 387 P.2d 833, 36 Cal. Rptr. 33 (1963); Union Oil Co. v. Chandler, 4 Cal. App. 3d 716, 84 Cal. Rptr. 756 (1st Dist. 1970). For discussion of independent actions for such damages, see text accoinpanying notes 193-202 infra.

If the tenant's attorney feels that the amount of damages awarded for discomfort and annoyance is inadequate, he inay move for a new trial. Cal. Code Crv. Pro. $\$$ 
be viewed as "giving the tenant something for nothing." The tenant has given his discomfort and annoyance in amounts which the factfinder could quantify as exceeding the contract rent. One would not think of limiting an award for the paim and suffering of a plaimtiff injured by a defective ten-dollar electric iron to $\$ 9.99$ to prevent him from getting the iron "for nothing."

\section{IV}

\section{Protective Orders}

In Green it was argued that consideration of the warranty of habitability issue in an eviction action would undermine the speedy procedure contemplated for unlawful detainer actions. ${ }^{124}$ The court rejected this argument, relying on the several out-of-state decisions and model codes which allow the defense and recognize the desirability of resolving all disputes between the parties in one proceeding. The court went on, however, to note that certain "procedural safeguards" are available "to protect the landlord's economic interests without depriving the tenant of a ineaningful opportunity to raise the breach of warranty issue."125 The court then adopted a procedural device endorsed in Hinson: where the tenant raises the implied warranty defense, "the trial court may, during the pendency of the action and at the request of either party, require the tenant to inake rental payinents at the contract rate into court as they become due for as long as the tenant remains in possession. At the trial of the action the court can then determine how the rent paid into court shall be distributed."126 The court in Green said that "[s]uch a procedure can serve as a fair means of protection of landlords from potential abuses of the proposed warranty of habitability defense."127

While neither Hinson nor Green exphicitly stated the economic interest it was protecting, the potential abuse it was guarding against, or how this tends to rebut the speedy procedure argument, the analysis

657(5) (West 1972). See also 5 B. Witkin, California Procedure 3619 (2d ed. 1971). Orders granting new trials because of inadequate awards for pain and suffering were upheld in Frantz v. McLaughlin, 64 Cal. 2d 622, 414 P.2d 410, 51 Cal. Rptr. 282 (1966), and in Peri v. Calley, 119 Cal. App. 117, 6 P.2d 86 (1st Dist. 1931). Denial of the inotion for new trial may be the basis for an appeal, as inadequate awards for pain and suffering have been reversed by appellate courts. See Haskins v. Holmes, 252 Cal. App. 2d 580, 60 Cal. Rptr. 659 (2d Dist. 1967); Bencich v. Market St. Ry. Co., 20 Cal. App. 2d 518, 67 P.2d 398 (1st Dist. 1937). See also 4 B. WITKIN, CaLIFORNIA LAw 3220-22 (8th ed. 1974).

124. 10 Cal. 3d 616, 636, 517 P.2d 1168, 1181, 111 Cal. Rptr. 704, 717 (1974).

125. Id. at $636,517 \mathrm{P} .2 \mathrm{~d}$ at $1182,111 \mathrm{Cal}$. Rptr. at 718 . 1972).

126. Hinson v. Delis, 26 Cal. App. 3d 62, 71, 102 Cal. Rptr. 661, 666 (1st Dist.

127. $10 \mathrm{Cal} .3 \mathrm{~d}$ at 637,517 P.2d at $1182,111 \mathrm{Cal}$. Rptr. at 718. 
would appear to be as follows. One of the key reasons for giving landlords a speedy remedy in eviction cases based on nonpayment of rent is the danger that a judgment-proof tenant will continue in possession during lengthy litigation-thereby depriving the landlord of the ability to rent the premises to someone who will pay rent. ${ }^{128}$ Moreover, such a tenant might raise the implied warranty defense to protract the litigation and thereby stay in possession rent-free for a longer period. Requiring him to pay the contract rent into court as it comes due thus serves two purposes. It removes an incentive for the indigent tenant to raise the implied warranty defense frivolously, thus protecting the courts as well as the landlord, and it protects the landlord from eventual loss of rent where the defense, although raised in good faith, is proven not meritorious.

A landlord's protection through this device, however, is subject to one important limitation. The courts in both Hinson and Green apparently recognized that the landlord's financial interest extends only to possible rent loss caused directly by a tenant's raising the defense, ${ }^{120}$ and therefore expressly limited the protective order to rental payments "as they become due."130 That is, since raising the implied warranty

128. This rent or rental value is recoverable in unlawful detainer cases, even though it accrues after the filing of the complaint. Flournoy v. Everett, 51 Cal, App. 406, 408, 196 P. 916, 917 (2d Dist. 1921); Holland v. Eastern Outfitting Co., 16 Cal. App. 441, 443, 111 P. 562, 562-63 (1st Dist. 1911).

129. Of course, the litigation itself can "cause" the landlord to lose past-due rent whenever the tenant becomes insolvent between the landlord's filing and fimal adjudication. But this danger is present in any lawsuit for money damages and is not related to that peculiar aspect of unlawful detainer which necessitates the speedy remedy, that is, the "using up" of the plaintiff's property by the defendant during litigation.

130. Hinson v. Delis, 26 Cal. App. 3d 62, 71, 102 Cal. Rptr. 661, 666 (1st Dist. 1972), quoted in Green v. Superior Court, $10 \mathrm{Cal}$. 3d 616, 637, 517 P.2d 1168, 1182, 111 Cal. Rptr. 704, 718 (1974). See also Blanks v. Fowler, 459 F.2d 1282, 1284 (D.C. Cir. 1971); Cooks v. Fowler, 459 F.2d 1269, 1276 n.59 (D.C. Cir. 1971) ("a pretrial protective order cannot properly require payment of rent accruing prior to its entry"); Bell v. Tsintolas Realty Co., 430 F.2d 474, 483 (D.C. Cir. 1970) ("fnture payments falling due after the date the order is issued"); Javins v. First Nat'l Realty Corp., 428 F.2d 1071, 1083 n.67 (D.C. Cir.), cert. denied, 400 U.S. 925 (1970) ("future rent payments . . . as they become due"); King v. Moorehead, 495 S.W.2d 65, 77 (Mo. Ct. App. 1973) ("as it becomes due").

Language in Bell indicates that the District of Columbia cases have employed an analysis slightly different from that outlined in the text. Since the District of Columbia rules do not permit the 1andlord to recover rent in a summary action for possession, courts there liave reasoned that mcluding back rent in the protective order "would depart from this protective purpose." Bell, supra, 430 F.2d at 483 . Similarly, since California does permit recovery of rent in a summary action for possession, no protective purpose would be served by imcluding back rent in the protective order in California.

Following its brief mention of protective orders, the Court in Green referred to section 4.105 of the Uniform Residential Landlord and Tenant Act. This reference was not well considered. Section 4.105 provides that in an action for possession based on nonpayment of rent, the tenant inay counterclaim for any amount he may recover under the agreement or Act, including damages for breach of implied warranty of habitability. 
defense does not affect the landlord's risk of losing any unpaid rent accrued prior to litigation, sucli past-due rent is not includable in the protective order. ${ }^{131}$ While this much seems clear, several issues regarding the protective order remain.

If the tenant counterclaims, however, "the court from time to time may order the tenant to pay into court all or part of the rent accrued and thereafter accruing." UNIFORM RESIDENTIAL LANDLORD \& TENANT ACT $\$ 4.105$ (a) (emphasis added). While allowing a counterclaim provides a much broader reinedy that permitting a defense based on brcach of the implied warranty, this does not explain why the court should have power to condition a couterclaim on payment of accrued rent. The justification for allowing protective orders where counterclaims are raised is the same as where defenses are raised: to discourage frivolous claims and protect the landlord from loss during litigation of the tenants' clain. These purposes are served by requiring payment of rent as it accrues. That the comment to this section of the Act fails to discuss this is perhaps explamed by the fact that the Act is essentially a political compromise. Landlord interests were opposed to permitting counterclaims. The compromise allows counterclaims, but effectively prevents many tenants from raising them through the accrued rent precondition. See Moskovitz, The Model Landlord-Tenant Code-An Unacceptable Compromise, 3 URBAN LAW. J. 597 (1971).

Fritz v. Warthen, - Minn. - , - 213 N.W.2d 339, 343 (1973), allowed the trial court to order withheld rent paid into court. While this language appears to refer to future rent, it could instead be construed as referring to past rent, since the court went on to add that "until final resolution on the merits, any future rent withheld shall also be paid into court." Id. (emphasis added) (footnote omitted). An examination of the court's reasons for allowing protective orders does not clarify this issue. The court first expressed concern that "pending final determination of the tenant's claim of breach of the statutory covenants, the landlord will be deprived of all or a portion of the rent while the tenant remains in possession," and that this may prevent the landlord from making repairs. Id. Second, in some cases the landlord, unable to evict the tenant and rent to someone else "during the delays occasioned by court proceedings," may win against a judgment-proof tenant. Id. While the second reason would seem to justify protective orders encompassing only future rent (the only rent endangered by the delays), the first reason might justify the payment into court of both past and future rent, assuming that the landlord can get this money paid out to him during the litigation. The merits of this latter assumption are questionable, as will be discussed later. In addition to the court's confusing language on this matter, the failure of the court in Fritz to consider, as the court in Bell did, the threatened interests of the tenant might diminish the precedential value of this portion of the opinion.

Moreover, requiring the tenant to pay accrued rent into court as a condition to litigate defenses might well be subject to constitutional challenge on due process and equal protection grounds. See Amanuensis, Ltd. v. Brown, 65 Misc. 2d 15, 23, 318 N.Y.S.2d 11, 20-21 (N.Y. City Civ. Ct. 1971); Clay v. Stovall, No. C-741-N (N.D. Ga., filed Jan. 2, 1974), summarized in 7 CLEARINGHOUSE REV. 618; compare footnote 153 infra. Note that in Lindsey v. Normet, 405 U.S. 56 (1972), the Supreme Court upheld an Oregon protective order requirement only as to "the payment of rent during the coutinuance of the action." Id. at 65 (emphasis added). Because of its reading of the Oregon statute involved, the Court did not need to consider a requirement that accrued rent be paid into court. Id. at $60 \mathrm{n} .3$. Lindsey went on to hold that requiring the tenant to post an appeal bond for double the amount of rent coming due during the appeal denies the tenant equal protection of the law vis-a-vis other appellants, since the doubling "bears no reasonable relationship to any valid state objective." Id. at 76-77. Arguably the same is true of requiring that accrued rent be paid into court during litigation.

131. "Judicial protection of the landlord, whether pretrial or post-trial, can be justified only within the area of fair compensation for the possession he loses during the period of litigation." Cooks v. Fowler, 459 F.2d 1269, 1274 (D.C. Cir. 1971). 


\section{A. Protective Orders Before Trial}

The brevity of the courts' discussions of protective orders in Hinson and Green might lead one to assume that these courts intended to authorize such orders in all cases in which the implied warranty defense is raised. Such a construction would mistakenly fail to deal with some difficult issues underlying this matter.

Protective orders are discussed more fully in Bell v. Tsintolas Realty Co. ${ }^{132}$ a decision by the District of Columbia Court of Appeals. In Bell the court first noted both the interests served and the interests threatened by such protective orders. Against allowing an order it placed the following factors: (1) It is highly unusual, as generally the plaintiff in a civil action has no protection against the defendant's insolvency; ${ }^{133}$ (2) it is inconsistent with the trend of recent cases giving indigent civil litigants greater riglits to proceed in forma pauperis, as it erects a monetary barrier to the indigent tenant's right to present his defense; ${ }^{134}$ and (3) it is rarely needed because tenants generally default or confess judgment. ${ }^{135}$ Thus, such an order creates a substantial risk of precluding litigation of meritorious defenses ${ }^{\mathbf{1 3 0}}$ and "carries a substantial risk of upsetting the precarious balance of tactics in landlord-tenant litigation." ${ }^{137}$ In favor of allowing a protective order the court arrayed other factors: ${ }^{138}$ (1) The landlord's need to prevent loss of nonrecoverable rent due to an imdigent tenant's retention of the premises during hitigation of the implied warranty defense is great; ${ }^{130}$ and (2) the burden of the protective order is "neither heavy nor

132. 430 F.2d 474 (D.C. Cir. 1970).

133. Id. at 479 \& n. 10 .

134. 430 F.2d at 479-80. On this point, the court cited Sniadach v. Family Finance Corp., 395 U.S. 337 (1969), thereby suggesting that requiring an indigent tenant to pay rent into court as it comes due in order to raise a defense might deny the tenant due process of law. (The California Supreme Court cited Bell with apparent approval on this issue in Blair v. Pitchess, 5 Cal. 3d 258, 281, 486 P.2d 1242, 1258, 96 Cal. Rptr. 42, 58 (1971).) However, in Lindsey v. Normet, 405 U.S. 56, 65 (1972), the Supreme Court upheld a very similar Oregon requirement. Compare note 130 supra.

135. Id. at 481.

136. Id.

137. Id. at $480-81$.

138. Id. at 481.

139. Id. at 482. The court also deemed "of great consequence" the fact that the landlord was seeking only possession, not possession plus judgment for rent due. Id. at 477-78. Where the landlord seeks only possession he is provided a speedy and summary procedure which allows the landlord to serve the summons by posting in some cases, while denying the tenant any counterclaims. These benefits are not present where the landlord also seeks a rent judgment. See generally Cooks v. Fowler, 459 F.2d 1269, 1276 (D.C. Cir. 1971).

In California, this distinction is of no consequence, since the unlawful detainer statutes do not make the remedy any less speedy or summary where the landlord seeks rent as well as possession. See CAL. Code CIv. Pro. $\$ \$ 1161-74$ (West 1973). 
unexpected,"140 since the tenant voluntarily assumed the obligation to make contract rental payments when he entered into the rental agreement.

The court in Bell resolved this conflict with a compromise, holding that protective orders are authorized but not favored and should be allowed "only in limited circumstances, only on motion of the landlord, and only after notice and opportunity for a hearing on such a 1notion," 141 including oral argument. ${ }^{142}$ The "limited circumstances" which the landlord must prove ${ }^{\mathbf{1 4 3}}$ at the hearing initially require the landlord to denionstrate "an obvious need for such protection."144 In determining whether this need exists, the trial court may consider

the amount of rent alleged to be due, the number of months the landlord has not received even a partial rent payment, the reasonableness of the rent for the premises, the amount of the landlord's monthly obligations for the premises, whether the tenant has been allowed to proceed in forma pauperis, and whether the landlord faces a substantial threat of foreclosure. ${ }^{145}$

The last factor would seem to involve a showing that the landlord does not have adequate income from other sources to meet mortgage payments and that the mortgagee is in fact considering foreclosure. ${ }^{146}$

140. 430 F.2d at 482 .

141. Id. at 479,483 .

142. Id. at 483 .

143. Id. at 483-84. That the burden of proof is on the landlord (movant) was reaffirmed in Blanks v. Fowler, 437 F.2d 677, 678 (D.C. Cir. 1970) and in a later decision by the same name, Blanks v. Fowler, 459 F.2d 1282, 1285 (D.C. Cir. 1971).

144. 430 F.2d at $483-84$.

145. Id. at 484. The court did not explain how each of these factors relates to the landlord's "need" for a protective order. The amount of rent allegedly due, the number of months the tenant has not paid any rent, and the fact that the tenant is proceeding in forma pauperis, all appear to be indicators of the tenant's insolvency, thus bearing on the two purposes of the protective order discussed earlier. See text accompanying notes 138-40 supra. The reasonableness of the rent, however, does not seem relevant to these purposes. The court may simply have been suggesting that if the rent is unreasonably high, the landlord should not be granted a protective order, since it is allowed on essentially equitable principles. See id. at 482 . The amount of the landlord's monthly obligations and the danger of foreclosure, on the other hand, relate to the purposes of the protective order only where the landlord shows that they will be pressing at the end of the litigation. Only then would the protective order itself help the landlord with these problems, for only then would he get the money paid into court (if he wins). A showing only that these factors are pressing when the landlord makes his motion does not demonstrate his need for the protective order so much as his need to lave the money paid from the court to him. As will be slown later, lowever, payment of the fund to the landlord before judgment should be allowed only in very narrow circumstances. See text accompanying notes 179-85 infra.

146. Cf. Blanks v. Fowler, 459 F.2d 1282, 1284 (D.C. Cir. 1971), where the court upheld a lower court finding that the landlord was in "obvious need" of a protective order even though the landlord held the building mortgage-free. The court pointed to evidence that one-third of the units were vacant at the time of hearing, that the operating deficit was $\$ 3,300$ and "still mounting," and that the landlord was "financially unable 
If the landlord demonstrates an obvious need for a protective order, the trial court must "compare that need with the apparent merits" of the tenant's defense. ${ }^{147}$ If that comparison indicates a strong possibility that the tenant will prove the landlord's breach of the implied warranty at trial, apparently the protective order should be denied. Finally, if the court decides that a protective order should be issued, it must then consider whether payment into court of an amount less than the contract rent would be appropriate. ${ }^{148}$ This may occur where the tenant makes a strong showing that the landlord has breached the warranty, ${ }^{140}$ where the tenant's financial condition has changed to make the burden of making full payments so heavy that he will be forced to give up his defense, ${ }^{150}$ or where the landlord does not require the full rent to meet his mortgage or tax payments. ${ }^{151}$

The approach outlined in Bell is, in general, ${ }^{152}$ a good one, taking into account both the legitimate purposes of the protective order and the dangers it poses to tenants wishing to raise the implied warranty

to absorb" this deficit. The court's analysis was incomplete in two respects. First, it failed to explain the nature of the "financial inability" to absorb the deficit. While a lack of other resources sufficient to maintain the building or give the landlord a decent standard of living might show an inability consistent with the obvious nced test, a mere inability to recover that portion of the loss represented by the tenaut's unpaid rent would not. Second, the court failed to inquire whether this "financial inability" would be present at the end of the hitigation, when the landlord would get the fund (if ho won). The fact that the deficit was "still mounting," however, might be viewed as a finding on this issue.

In Cooks v. Fowler, 437 F.2d 669, $674 \&$ n.23 (D.C. Cir. 1971), the court found need for a protective order from evidence that the landlord, a 79-year-old widow with two incompetent adult sons, was "dependent on the income from the apartment building" and that she faced a deficit of $\$ 3,500$ from operating the buillding. This finding suffers from the same two defects. The court did not discuss the nature of the landlord's dependence on income from the building, nor did it consider whether this dependence would still be present at the conclusion of the appeal.

The court's apparent laxity in dealing with the "obvious need" issue in these two cases is both ironic and unfortunate. It is ironic, because other aspects of these decisions seem carefully to preserve the tenant's interests on issues involving protective orders, as will appear later. It is unfortunate, because the court may be setting a poor example for trial courts which may be careless in considering evidence bearing on protective orders.

147. Bell v. Tsintolas Realty Co., 430 F.2d 474, 484 (D.C. Cir. 1970).

148. Id.

149. Id. Since the court had earlier stated that this would justify denying the order, the court in Bell apparently intended to give the trial court the choice of denying the order or lowering the rent to be paid into court when the tenant makes this "showing of merits." In Blanks v. Fowler, 437 F.2d 677, 678 (D.C. Cir. 1970), after an evidentiary hearing showed substantial code violations on the premises, the trial court granted the protective order but reduced the amount to be paid into court to approximately twothirds of the contract rate.

150. 430 F.2d at 484 .

151. Id. at 484-85.

152. See, however, the criticism at note 145 supra. 
defense in good faith. But the court failed to explain fully one of the important factors in the opimion-the "precarious balance of tactics in landlord-tenant litigation."153 Such an oversight is unfortunate, since inuch of the court's compromise approach is built upon this factor.

The usual eviction dispute is different from most litigation in one very important respect: the real question often is not whether the plaintiff-landlord will prevail, but when. Whenever a landlord sues to evict a month-to-month tenant for nonpayment of rent, the attorneys for both parties know that even if the tenant defeats this claim, the landlord can later terminate the tenancy by a 30-day notice, and there is little likelihood of defeating that claim. ${ }^{154}$ With a judginent-proof tenant, however, the duration of the litigation becomes important to each party-the landlord receives no rent, even upon judgment, for this period, and the tenant will have the premises rent-free for the period. Temporary free rent, however, is generally not the tenant's primary goal. Rather, it is a tactic directed toward a quite different goal, satisfactory resolution of the grievance which led to the rent-withholding in the first place.

Often the tenant's grievance involves the landlord's alleged failure to repair or maintain the premises. In the battle over this grievance, each side may employ a number of tactics, ${ }^{155}$ the most important usually being the landlord's attempt to evict and the tenant's attempt to withhold rent while remaining in possession. If the tenant is evicted, so is his grievance, and the landlord is satisfied. But if the tenant can withhold rent for a substantial period, he subjects the landlord to mounting financial pressure which, at some point, may be sufficient to force settlement of the underlying grievance. ${ }^{156}$ Thus, those tactics within the eviction litigation which affect its duration are quite important to the final outcome of the dispute. ${ }^{157}$

This, then, is the "precarious balance of tactics" into which the protective order intrudes. For the tenant, issuance of a protective order presents a Scylla and Charybdis choice. Failure to comply presumably will lead a court to strike his implied warranty defense, thus precluding him from hitigating the issue. On the other hand, compliance lessens the pressure on the landlord. Granted, the landlord will not necessarily receive the rent money prior to judgment, but with the money trans-

153. 430 F.2d at 481 .

154. There may, however, be increasing opportunities to resist such termiuations. See note 230 infra; see generally text accompanying notes 230-46 infra.

155. See 2 National Housing and Development Law Project, Handbbook on Housing LAW ch. I, at 35-45 (1970).

156. Id. at 41 .

157. Such tactics are discussed at length in CaLIFornia EVIction DEFEnSE MANUAL, supra note 13. 
ferred from the tenant's possession into the court, his chances at least increase. ${ }^{158}$ Moreover, even if appellate opinions disfavor prejudgment "turnover" orders, many lower court judges are sympathetic to landlords and may turn the money over to the landlord in questionable cases.

Thus the actuality, and imdeed even the possibility, of protective orders affects the settlement-bargaining process in eviction litigation. A protective order removes a measure of control formerly lield by the tenant-the financial pressure of withheld rent; a turnover order renders this tactic nugatory. The court in Bell was aware of the importance of landlord-tenant tactics. Indeed, it accepted their legitimacy by expressly including this delicate tactical balance as a basis for its decision. Its conclusion that protective orders are permitted but not favored is an accommodation as much to these tactics as to any other factor. The compromise reached, if strictly adhered to, slould serve to minimize the upsetting nature of such orders. ${ }^{159}$

\section{B. Protective Orders Pending Appeal}

The tenant who appeals an unlawful detainer judgment against

158. See text accompanying notes $168-85$ infra.

159. Practice note-attacking an improper protective order: The trial court's discretion in framing protective orders should be exercised within the bounds of the guidelines discussed above. Where the trial court abuses this discretion, the tenant should seek a writ of mandate from an appellate court compelling the lower court to set proper conditions. Cf. Candeias v. Superior Court, 49 Cal. App. 580, 193 P. 957 (3d Dist. 1920); CaIIfornia Eviction Defense Manual, supra note 13, $\S 18.1-18.18$ at 172 79 (writs of mandate in eviction cases).

If the tenant has been denied a stay by the lower court or cannot meet the conditions of the stay, however, he can prevent eviction while waiting for the appellate court to rule on his petition for writ of mandate only by applying for a temporary stay from the appellate court itself, pending its decision on the petition. Id. $\$ 18.17$, at 178. But the issue then arises as to whether that court may condition its stay on a protective order. Such an order was in fact issued by the Supreme Court in Green, without discussion. The court stayed execution "conditioned on the tenant's payment into court of all rent which had accrued since the superior court judgment and all future rent as it bccame due." $10 \mathrm{Cal}$. 3d at 622, 517 P.2d at 1171, $111 \mathrm{Cal}$. Rptr. at 707. As discussed earlier, the payment into court of rent accrued before the date of the protective order is not justified by the legitimate purposes of the protective order. See notes $30,146,173$ supra. Therefore, the portion of the court's order requiring payment of rent "accrued since the superior court judgment" is not justified. See Jack Spring, Inc. v. Little, 50 Ill. 2d 351, 356, 280 N.E.2d 208, 212 (1972).

The Court of Appeals for the District of Columbia faced this precise issue in its first opinions in Cooks v. Fowler, 437 F.2d 669 (D.C. Cir. 1971), and Blanks v. Fowler, 437 F.2d 677 (D.C. Cir. 1970). The court held in Cooks that it should issue stays conditioned on protective orders when reviewing the propriety of post-judgment protective orders entered by trial courts. In Blanks, the court limited its protective order to an amount less than the contract rent of $\$ 72.50$, in accordance with the trial court's finding (at its hearing on the issuance of a pretrial protective order) that the warranty of habitability had been breached and that a reasonable reutal was only $\$ 50.00$. This approach is proper under the reasoning discussed earlier. 
him $^{160}$ will have to obtain a stay of execution of the judgment if he wants to remain im possession of the premises during the appeal. Unlike most other civil actions in California, the tenant receives no automatic stay by filing a notice of appeal and giving an undertaking, for the trial judge is given discretion to grant or deny a stay. ${ }^{101}$ While no California case so holds, it would seem that this discretion must include the power, in appropriate circumstances, to grant a stay while attaching to it certain conditions, such as a protective order.

The Court of Appeals for the District of Columbia upheld this power in Cooks v. Fowler. ${ }^{162}$ Generally following the analysis in $B e l l,{ }^{163}$ the court limited protective conditions on appeal to "appropriate situations," while maintaining Bell's requirements that protective orders be granted only on motion of the landlord and after the tenant has an opportunity for a hearing. ${ }^{164}$ The court stated: "We perceive nothing in law or logic that could vindicate a rule demanding less for protective orders pending appeal."105 It did indicate, however, one apparently significant difference in requirements for protective orders prior to litigation and those pending appeal. While the former require the landlord to demonstrate an obvious need for the protective order, the court suggested it might not demand such a showing in the latter instance. It reasoned that Bell's rationale depended largely on "the extraordinary character of prejudgment security deposits in American jurisprudence," while post-judgment security requirements are "by no means unusual."106 Also, if the tenant lost at trial, it seems fair to start the appellate process with the presumption that his defense was not valid, an impermissible assumption at a pretrial hearing. These distinctions would seem to support a rule requiring the tenant, like any other appellant, to provide some security for the landlord during the appeal, even in the absence of any showing of obvious need by the landlord. ${ }^{107}$

160. Where the tenant wins in the trial court and the landlord appeals, any protective order in effect should be dissolved, and no new order should be issued during the appeal. See Bell v. Tsintolas Realty Co., 430 F.2d 474, 483 (D.C. Cir. 1970) ("if the tenant prevails on the trial level, any prepayment order will be discontinued").

161. Cal. Code Civ. Pro. $\$ 1176$ (West 1972). See California Eviction Defense Manuar, supra note $13, \S 17.6$, at 163 (1971).

162. 459 F.2d 1269, 1272 (D.C. Cir. 1971).

163. Bell v. Tsintolas Realty Co., 430 F.2d 474 (D.C. Cir. 1970).

164. Presumably, this motion could be made during the hearing on the tenant's application for a stay during the appeal.

165. $459 \mathrm{~F} .2 \mathrm{~d}$ at 1275.

166. Id. Such requirements are not unusual in California either. See CAL. CODE Crv. Pro. $\S \S 916-23$ (West 1972).

167. How much rent can the tenant be ordered to pay into court under a post-judgment protective order? The upper limit, of course, should be the contract rent. Cooks v. Fowler, 459 F.2d 1269, 1274 (D.C. Cir. 1971). An amount equal to the rent should be paid into court as the rent becomes due during the appeal. Id. at 1276. See also 


\section{Turnover Orders}

Some landlords will not be satisfied with the protection afforded by a protective order and will seek to obtain the fund itself during litigation. ${ }^{168}$ As the court in Bell recognized, adding a device such as the protective order to the landlord's procedural arsenal "carries a substantial risk of upsetting the precarious balance of tactics in landlordtenant litigation."169 The substantial risk created by the protective order, however, is minimal indeed when contrasted with the upsetting nature of a turnover order. As discussed earlier, a protective order relieves the landlord only of the long-range fear that rent for the period in question will never be forthcoming. On the other hand, a turnover order may negate the tenant's one tactical weapon by reheving the landlord of his much more immediate and real fear, that he will not have the finances to meet present expenses. In addition, if a turnover order is issued, the tenant must take the risk of the landlord becoming judgment-proof and thus unable to return the portion of the rent representing the tenant's daunages for breach of the implied warranty.

A District of Columbia court implicitly recognized this in an earlier decision, Dorfmann v. Boozer. ${ }^{170}$ In that case a group of ten-

Jack Spring, Inc. v. Little, 50 IIl. 2d 356, 280 N.E.2d 208 (1972). In this second Cooks opinion, however, the court held that the trial court must consider whether an amount less than the contract rent would be more appropriate. In that case the landlord sued to evict on two grounds: failure to pay rent and holdover after a 30-day notice to vacate. A breach of implied warranty was found by the jury, defeating the claim based on nonpayment of rent. The jury also found, however, that the 30-day notice was not retaliatory. When the tenant appealed this latter issue, the trial court granted a stay of eviction conditioned on a protective order compelling the tenant to pay future rent into court at the contract rate. The Court of Appeals held this to be error. Since the landlord had breached the implied warranty, he would be entitled only to a reasonable rental, less than the contract rate. Since this was all he stood to lose during the appeal, the protective order should cover only this amount. While the reasonable rent may be difficult to ascertain, for purposes of entering a protective order (which is a provisional remedy, not a final one), only an "inforned estimate" by the trial court is necessary. $I d$. at 1274-75. The court went on to say that even where the jury finds no breach of the implied warranty, this "does not warrant a judge's failure to consider a sum less than stipulated rent as the amount of protective order deposits," since it is the judge's duty, not the jury's, to formulate the protective order. Id. at 1275. There is no real confliet with the jury's verdict in any event. The jury's finding of no breach covers, at most, the period up until the date of its finding, while the court's task is to estimate the possible loss to the landlord during the appeal. In doing so it might find that conditions on the premises are deteriorating and will constitute a breach during the appeal. While the jury's finding may raise a presumption that the status quo-that is, no breach-will continue, that presumption is rebuttable. Compare text accompanying notes 201-03 infra.

168. Cf. M \& M Associates v. John Alvarado, (1972-74 Transfer Binder) $\mathrm{CCH}$ Pov. L. ReP. I 16,240 (N.Y. City Civ. Ct. 1972), where the court allowed the tenant to obtain part of the fund before judgment in order to begin needed repairs. See also note 145 supra.

169. 430 F. 2 d 474,481 (D.C. Cir. 1970).

170. 414 F.2d 1168 (D.C. Cir. 1969). 
ants had formed a tenants' union to deal with a landlord who failed to remedy code violations. The tenants withheld their rent and paid it into a bank account opened by the tenants' union. The landlord then brought suit for an imjunction to compel the union to turn the money over to the landlord. After finding that the landlord was without operating funds, that it had a monthly deficit of $\$ 23,000$, and that its loan was in default, with foreclosure imminent, the trial court issued a preliminary injunction ordering the union to pay the money into court, where the money would be "subject to further disposition by this Court" on application by either party. ${ }^{171}$ The court of appeals reversed the order granting the preliminary injunction, reasoning that "there is a comprehensive statutory scheme for landlord and tenant actions, including detailed provision for attachment prior to judgment in narrowly and precisely defined instances."172 The landlord, it ruled, should not be allowed to undercut this scheme by forcing the money withheld to be paid into court before judgment and then obtaining the nnoney. ${ }^{173}$ Without deciding whether such rehef could ever be permitted, the court held that financial hardship of the landlord would not justify it where the injunction would "alleviate the hardship of one party by exposing the other party to great financial risk." In where the tenants claimed a right to the withheld rent, payment to the landlord before litigation of the tenants' right to the inoney might jeopardize their ability to recover it if and when they won the right to it. This danger is far from theoretical where the landlord has just proven his financial hardship, thereby also indicating the likelihood of his current or pending insolvency. ${ }^{175}$

Where a landlord seeks for himself money that the tenant has paid into court under a protective order, the same considerations which concerned the court in Dorfmann are present. Sucl action eonstitutes an

171. Id. at 1171 .

172. Id. at 1171. The same is true in California. See CaL. Code CIv. Pro. \$§ 1159 et seq. (West 1972, West Supp. 1974) (summary remedies in forcible entry and unlawful detainer actions); CAL. CIV. CODE $\$ 1861$ a (West Supp. 1974) (giving landlord a lien on certain belongings of the tenant, enforceable by court order after a noticed hearing). Other sections of the Code of Civil Procedure provided the landlord with prejudgment attachment of the tenant's property to secure the claim for rent, but they were declared unconstitutional for failure to provide the tenant a prior hearing. See Randone v. Appellate Dep't, 5 Cal. 3d 536, 488 P.2d 13, 96 Cal. Rptr. 709 (1971); Damazo v. MacIntyre, 26 Cal. App. 3d 18, 102 Cal. Rptr. 609 (2d Dist. 1972).

173. 414 F.2d at 1172. See also Warking Barker Co. v. Nestenpower, (1972-74 Transfer Binder) CCH Pov. L. ReP. If 17,653 (N.Y. Sup. Ct. 1973).

174. 414 F.2d at 1773 .

175. There is language in Dorfmann indicating that requiring the landlord to post a bond may take care of this risk-shifting problem. Id. at 1173. Bnt this would not satisfy the other basis for the decision, the policy of not allowing the landlord to evade a "compreliensive statutory sclieme" designed to strike a delicate balance between the needs of landlords and tenants. Id. at 1171. 
attempt to undercut a comprehensive statutory scheme which allows the landlord to recover rent money only through specified procedures. A landlord's success in this attempt shifts the risk of monetary loss to the tenant. Moreover, since the landlord is required to show some financial hardship in order to prove an obvious need for the protective order, ${ }^{176}$ this risk of loss is quite likely to be substantial.

The same court, in its first Cooks opinion, ${ }^{177}$ recognized this similarity between the landlord's approach in Dorfmann and a landlord's quest for the fund paid into court under a protective order. In denying the landlord's motion for a turnover order, the court, citing Dorfmann, noted:

The landlord's protective order, like the injunction, is 'an equitable remedy' ... and is similarly circumscribed. And, with an apparently financially insecure landlord, no more here than in Dorfmann could we shift the risk to the tenant prior to decision on the merits of the appeal-a decision which might absolve the tenant of any compensatory responsibility. ${ }^{178}$

In its second Cooks opinion, however, the court noted in dictum that there might be "a small, sharply circumscribed area in which a turnover of some part of the fund might be vimdicated."170 It delimited this area in three ways. First, such a turnover can apply only to that pant of the fund to which the landlord will necessarily be entitled at the end of the litigation. Thus, suppose the contract rent is $\$ 150$ per month and the tenant lias paid this amount into court under a protective order. If, at a hearing on the landlord's motion to obtain the fund, the tenant claims that a reasonable rent is less than $\$ 150$ but concedes that it is at least $\$ 50$, then the $\$ 50$ is subject to a turnover order. If the tenant claims that a reasonable rent is zero, then no part of the fund is subject to turnover. The tenant's claim must be honored by the court for this purpose, so long as it is "non-frivolous."180 Second, the landlord may not obtain even this pant of the fund unless he "demonstrates convincingly" that his "immediate need is extreme."181 This strong language indicates that the landlord's showing of need here must be greater than the showing of obvious need he made to get the protective order issued, a quite proper requirement considering the serious threat a turnover order poses for "the precarious balance of tac-

176. See Bell v. Tsintolas Realty Co., 430 F.2d 474, $483-84$ (D.C. Cir. 1970). Compare notes 145-46 supra.

177. Cooks v. Fowler, 437 F.2d 669, 676 n.39 (D.C. Cir. 1970).

178. Id.

179. Cooks v. Fowler, 459 F.2d 1269, 1277 (D.C. Cir. 1971).

180. Id.

181. Id. 
tics in landlord-tenant litigation."182 And third, before any turnover order is made, these issues must "first be subjected to careful examination at a hearing after due notice."183

The cautious approaclı taken in these District of Columbia cases involving turnover orders is well reasoned. The danger that a turnover order may place the tenant in a substantially weaker settlement-bargaining position-before litigation of the merits of the case-is serious. ${ }^{184}$ Sucli a "prejudgment judgment" would thus be highly unfair, as well as highly unusual, unless it is confined to the narrow circumstances described in Cooks. ${ }^{185}$

\section{Distribution After Trial of Money Paid into Court Under a Protective Order}

In Hinson the court lield that "[a]t the trial of the action the court can then determine low the rent paid into court should be distributed." 180 While the court did not say how this should be done, again the District of Columbia decisions offer some guidance.

The District of Columbia Circuit set out the following procedures for distributing the money. If the tenant proves his defense, then the fund should be apportioned between landlord and tenant in accordance with the reasonable rent finding. ${ }^{187}$ Since the fund represents rent that accrued only during the litigation, ${ }^{188}$ distribution in accordance with the

182. Bell v. Tsintolas Realty Co., 430 F.2d 474, 481 (D.C. Cir. 1970). See text accompanying notes 154-58 supra.

183. 459 F.2d at 1277 . In a brief dictum, the court in King v. Moorehead, 495 S.W.2d 65 (Mo. Ct. App. 1973), appeared to adopt the essence of the Cooks test (although Cooks was not cited) on turnovers: "[F]or good cause and in a manner consistent with the ultimate right betweeu the parties, a trial court will have discretion to make partial distribution to the landlord before fimal adjudication when to deny it would result in irreparable loss to him." Id. at 77.

184. A slightly different concern was expressed by the court in $176 \mathrm{E} .123 \mathrm{rd}$ St. Corp. v. Flores, 65 Misc. 2d 130, 317 N.Y.S.2d 150 (N.Y. City Civ. Ct. 1970). When the tenant ceased making required payments into court, the landlord moved to have the fund turned over to him. In denying the motion, the court said that to turn over the fund to the landlord would encourage other landlords to do nothing to eliminate defects, and would "reduce the court to a rent collector." Id. at 133, 317 N.Y.S.2d at 153.

185. Practice note: An improper turnover order miglit be attacked in an appellate court by a petition for writ of prohibition. See 5 B. WitkIN, CallForNIA Procedure 3809 et seq. (2nd ed. 1971).

186. Hinson v. Delis, 26 Cal. App. 3d 62, 71, 102 Cal. Rptr. 661, 666 (1st Dist. 1972), quoted in Green v. Superior Court, 10 Cal. 3d 616, 637, 517 P.2d 1168, 1182, 111 Cal. Rptr. 704, 718 (1974).

187. Javins v. First National Realty Corp., 428 F.2d 1071, 1083 n.67 (D.C. Cir.), cert. denied, 400 U.S. 925 (1970). Thus, suppose the contract rent is $\$ 150$ per month and the tenant was required to pay one month's rent into court under a protective order issued before trial. At trial, he wins lis defense and a reasonable rent is determined to be $\$ 100$. Of the fund of $\$ 150$, therefore, $\$ 100$ is distributed to the landlord and $\$ 50$ to the tenant.

188. In Javins the court stated that the money paid into court would "represent rent 
reasonable rent formula assumes that the breach continued throughout the litigation. Javins allows either party to challenge this assumption by amending its complaint or answer to allege that conditions have changed either for better or for worse during the litigation. Following such an allegation, the fact-finder must make a separate finding of whether there was a breach during that period and, if so, of the reasonable rent for that period; the fund is distributed accordingly. ${ }^{180}$

By the same reasoning, if the tenant fails to prove his defense at trial, it is assumed that no breach of warranty occurred during the litigation, so the landlord will ordinarily receive the whole fund. Here too the tenant may attempt to rebut this assumption by proving a breach during the litigation. If he is successful, the fund is distributed according to a reasonable rent finding on this issue. ${ }^{100}$ Lastly, if the tenant vacates the premises before the litigation is concluded, the fund should nonetheless be distributed according to the above principles. ${ }^{101}$

for the period between the time the landlord files suit and the time the case comes to trial." Id. at 1083 n.67. This reference to the time the landlord files suit rather than the time the protective order is issued would seem to be a mistake. It is inconsistent with the court's earlier express limitation on the protective order to "future rent payments" and it does not appear to be required by the purposes which underlie the protective order. Rents paid into court pursuant to a protective order should represent rents accrued since the date of the order only. Rents accruing prior to this, even if they accrued after the date the lawsuit was filed, should be awarded by judgment to the landlord if he wins and should be reduced to a reasonable rent if the tenant proves the breach of warranty. Cf. Flournoy v. Everett, 51 Cal. App. 406, 408, 196 P. 916, 917 (1st Dist. 1921); Holland v. Eastern Outfitting Co., 16 Cal. App. 441, 117 P. 562 (1st Dist. 1911).

189. 428 F.2d at 1083 n.67; see also Bell v. Tsintolas Realty Co., 430 F.2d 474, 485 (D.C. Cir. 1970).

190. Bell v. Tsintolas Realty Co., 430 F.2d 474, 485 (D.C. Cir. 1970).

191. See Morbeth Realty Corp. v. Velez, 73 Misc. 2d 996, 343 N.Y.S.2d 406 (N.Y. City Civ. Ct. 1973). Cf. Bell v. Tsintolas Realty Co., 430 F.2d 474, 485 (D.C. Cir. 1970), where the court said that if the tenant abandons before trial, the fund should be returned to him unless the landlord promptly goes to court and seeks a judgment for rent. The court was dealing with a situation where the initial suit sought possession only, not possession plus rent. Id. at 477 . Under such circumstances the court may justifiably require the landlord to file a new suit if he wants to recover rent through getting part of the fund. In California, the landlord can, and usually does, seek rent as well as possession in an eviction suit; thus a new suit to recover part of the fund is not required. See note 152 supra.

Practice note: As discussed earlier, a protective order should not apply to allegedly unpaid rent coming due before the date of the order. See note 130 supra. Nevertheless, when the tenant's attorney decides to raise an implied warranty defense, he should consider advising his client to pay all unpaid rent into the attorney's trust account and, if no protective order is later issued, to pay accruing rent into the account as it comes due. This may help the tenant in several ways. First, the tenant's agreement to this arrangement may persuade the court that a protective order requiring payment into court is unnecessary. Second, it may help to win the defense itself. The fact that the tenant has not simply pocketed the rent money should impress the court that the tenant is sincerely attempting to get repairs made, not merely trying to make some easy money or concoct a defense after becoming unable to pay rent. Third, even if the tenant proves a breach 


\section{OTHER REMEDIES FOR BREACH OF WARRANTY}

While tenants will probably use the implied warranty doctrine most often as a defense to an eviction action, it should also lead to other remedies for the tenant. Since the doctrine views the rental agreement as a contract, other contract remedies should be permitted. This, in fact, was expressly intended by several of the courts which have adopted the implied warranty doctrine. As the Hawain Supreme Court stated:

By adopting the view that a lease is essentially a contractual relationship with an implied warranty of habitability and fitness, a more consistent and responsive set of remedies are available for a tenant. They are the basic contract remedies of damages, reformation, and rescission. These remedies would give the tenant a wide range of alternatives in seeking to resolve his alleged grievance. ${ }^{192}$

\section{A. Damages}

Traditionally, damages for breach of contract measure lost expectation, focusing on economic imjury. For reasons discussed previously, ${ }^{193}$ however, discomfort and annoyance describe more precisely the tenant's injury from breach of the implied warranty. Accordingly, he should be allowed to sue for any such injuries suffered during the entire period the landlord was in violation of the imphed warranty. ${ }^{194}$ While these damages would be effectively limited to the con-

of the implied warranty, he will have to pay a reasonable rent for all months he has not paid. What this reasonable rent will be cannot be predicted with any certainty before the issue is decided by the factfinder. It might closely approximate the contract rent. Unless the tenant has a fund available to pay this amount at the end of the trial, he will be evicted. In Academy Spires v. Brown, 111 N.J. Super. 477, 488, 268 A.2d 556,562 (Dist. Ct. 1970) the tenant was given only three days to come up with this money. Seven days were allowed in Morbeth Realty Corp. v. Rosenshine, 67 Misc. 2d 325, 328, 323 N.Y.S.2d 363, 367 (N.Y. City Civ. Ct. 1971).

Finally, having the fund available might increase the tenants bargaining power in settlement negotiations. It shows the landlord that the tenant is committed to seeing the dispute through to the end, and it provides a fund to be traded off in exchange for the landlord meeting the tenant's demands.

192. Lemle v. Breeden, 51 Hawaii 426, 436, 462 P.2d 470, 475 (1969). See also Javins v. First Nat1 Realty Corp., 428 F.2d 1071, 1082 n.61 (D.C. Cir. 1970), cert. denied, 400 U.S. 925 (1970) ("all contract remedies"); Mease v. Fox, 200 N.W.2d 791, 797 (Iowa 1972) ("basic contract remedies"); King v. Moorehead, 495 S.W.2d 65, 7576 (Mo. Ct. App. 1973); Kline v. Burns, 111 N.H. 87, 93, 276 A.2d 248, 252 (1971) ("basic contract remedies of damages, reformation, and rescission"); Morbeth Realty Corp. v. Rosenshine, 67 Misc. 2d 325, 327, 323 N.Y.S.2d 363, 366 (N.Y. City Civ. Ct. 1971) ("usual contract remedies"); Glyco v. Schultz, 35 Ohio Misc. 25, 33, 289 N.E.2d 919, 925 (Sylvania Mun. Ct. 1972) ("normal contract remedies").

193. See text accompanying notes 115-19 supra.

194. Cf. Steele v. Latimer, 214 Kan. 329, 521 P.2d 304 (1974); Gillette v. Anderson, 4 III. App. 3d 838, 282 N.E.2d 149 (1972). 
tract rent if claimed defensively in an eviction action ${ }^{106}$ there would be no such limit where the tenant brings an independent action. (Physical injury or illness, even propenty damage or related economic loss, may accompany or contribute to the tenant's discomfort and annoyance. Damages for these incidental injuries should also be recoverable on a breach of contract theory. ${ }^{196}$ )

Although generally these damages are the tenant's primary concern, there are times when economic loss not directly related to discom. fort and annoyance must also be considered. Thus, if the tenant has a lease and, because of the breach of warranty, vacates before expiration of the lease term, he should be entitled to the economic value of the lease for the unexpired term: the present value of the excess, if any, of the fair market rental of the premises over the contract rent. In this way the tenant would recover the benefit of his bargain. ${ }^{107}$

While punitive damages are not ordinarily allowed in breach of contract actions, ${ }^{108}$ they are allowed where the breach is also a tort. ${ }^{100}$ Since the impled warranty theory is essentially a tort-contract hybrid concept. ${ }^{200}$ the landlord who breaches the implied warranty also com1mits a tort. ${ }^{201}$ Punitive damages therefore should be allowed in appropriate cases, such as when the tenant shows oppression, fraud, or malice in the breach. ${ }^{202}$ Beyond this theoretical base, allowing punitive damages should further one of the purposes of the implied warranty doctrine, inducing landlord compliance with housing codes.

\section{B. Termination and Rescission}

Where there has been a breach of the implied warranty of habit-

195. See note 123 supra.

196. See Windeler v. Scheers Jewelers, 8 Cal. App. 3d 844, 851, 88 Cal. Rptr. 39, 44 (1st Dist. 1970); Mease v. Fox, 200 N.W.2d 791, 797 (Iowa 1972) ("incidental and consequential damages which fall within the general principles governing the allowance of such damages" are recoverable); cf. CAL. CoMM'L CoDE $\S \S 2714(3), 2715(2)$ (b) (West 1969).

197. Mease v. Fox, 200 N.W.2d 791, 797 (Iowa 1972); King v. Moorehead, 495 S.W.2d 65, 76 (Mo. Ct. App. 1973).

198. CaL. Crv. CoDE $\S 3294$ (West 1970). See also 4 B. WTrkIN, Summary of CALIFORNIA LAW 3142 et seq. (8th ed. 1973).

199. Wetherbee v. United Ins. Co. of America, $265 \mathrm{Cal}$. App. 2d 921, 927-29, 71 Cal. Rptr. 764, 767-69 (1st Dist. 1968); Fletcher v. Western Nat'l Life Ins. Co., 10 Cal. App. 3d 376, 89 Cal. Rptr. 78 (4th Dist. 1970).

200. See Prosser, The Assault Upon the Citadel (Strict Liability to the Consumer), 69 Yale L.J. 1099, 1126 (1960), cited in Javins v. First Nat'l Realty Corp., 428 F.2d 1071, 1076 n.19 (D.C. Cir.), cert. denied, 400 U.S. 925 (1970). See also Escola v. Coca Cola Bottling Co., 24 Cal. 2d 453, 466, 150 P.2d 436, 443 (Traynor, J., concurring); Note, Products Liability at the Threshold of the Landlord-Lessor, 21 Hast. L.J. 458, 460-61 (1970).

201. Compare Acadia, California, Ltd. v. Herbert, 54 Cal. 2d 328, 353 P.2d 394, 5 Cal. Rptr. 686 (1960).

202. CaL. CIV. Code $\$ 3294$ (West 1970). 
ability, it would seem that the tenant has the additional right to terminate the rental agreement and vacate, thereby ending any further obligation under the agreement. While a breach of contract must be material to permit termination, ${ }^{203}$ in implied warranty cases the finding of breach should by itself establish materiality, simce a finding that the defects were material is generally essential to a finding of breach. ${ }^{204}$

Rescission, however, goes beyond termination, restoring the parties to their former position by requiring each to return what he received under the agreement. ${ }^{205}$ Rescission requires that one party, through personal fault, has failed to supply full consideration for the contract. ${ }^{208}$ A landlord's breach of the implied warranty, based as it is on a conscious failure to repair defects, should establish fault, thus entitling the tenant to rescission and restitution.

In order to rescind, however, the tenant must give natice of rescission and offer to restore everything he has received under the agreement. ${ }^{207}$ This restoration appears to require that the tenant pay the landlord a reasonable rent for the premises during the period of breach if the tenant wants the return of the remainder of the rent payments he has made. ${ }^{208}$ This reasonable rent should be calculated by the same approacli used to determine the reasonable rent the tenant owes in an eviction action. ${ }^{209}$

The New Jersey Supreme Court has upheld the right of the tenant to recover rents paid-less the reasonable rent-during the period the landlord had breached the implied warranty of labitability. In Berzito v. Gambino $o^{210}$ the tenant had won a previous eviction action by proving that the landlord breached the implied warranty during the period for which the tenant withheld rent. ${ }^{211}$ The court liad lield that a reasonable rent was $\$ 75$ per month (rather than the $\$ 35$ per week contract

203. 1 B. WITkIN, SUMmary OF CaLIFornia LAW 528 (8th ed. 1973).

204. See text accompanying notes 63-68 supra.

205. 1 B. WITKIN, SUMMARY OF CALIForNia LAW 573 (8th ed. 1973).

206. CAI CTv. CODE $\$ 1689$ (b)(2) (West 1973). Depending on the facts, the tenant might also be able to invoke other grounds for rescission set out in section 1689 . See also Boston Housing Authority v. Hemingway, - Mass. -, -, 293 N.E.2d 831, 843-44 (1973).

207. CAL. Crv. Code $\$ 1691$ (West 1973). The tenant's pleading may serve as this notice and offer, if it is served promptly after discovering facts giving him the right to rescind (if he is aware of his right to rescind). II. The offer must include a tender of any rent due and unpaid for any period before the time of the landlord's breach of the imphed warranty. See Kulawitz v. Pacific Woodenware \& Paper Co., 25 Cal. 2d $664,669,155$ P.2d 24, 27 (1944).

208. See Berzito v. Gambino, 63 N.J. 460, 469, 308 A.2d 17, 22 (1973); Pines v. Perssion, 14 Wis. 2d 590, 597, 111 N.W.2d 409, 413 (1961).

209. See text accompanying notes $99-123$ supra.

210. 63 N.J. 460, 308 A.2d 17 (1973). See Blumberg \& Robbins, Retroactive Rent Abatement: A Landlord Tenant Remedy, 7 ClEARINGHOUSE REv. 323 (1973).

211. The defects are listed in text accompanying note 86 supra. 
rent). The tenant then sued the landlord to recover the difference between the contract rent and reasonable rent from the beginning of the tenancy until the commencement of rent withholding, claiming that the same defects had existed throughout. The trial court held for the tenant, ordering the landlord to return $\$ 1,180$ to him, ${ }^{212}$ and the New Jersey Supreme Court upheld this decision. ${ }^{213}$ While the court did not expressly use the terin rescission, it seems clear from its opinion that it considered the recovery to be based on a rescission theory, since it spoke of recovery of rent, not damages. ${ }^{214}$

In a rescission action, just as in an action for damages for breach of the iniplied warranty, the tenant should also be allowed to recover incidental and consequential damages for property damage, econounic loss, physical injury, or illness. ${ }^{215}$ But while the tenant might recover punitive damages in an action for damages based on the breach, ${ }^{210}$ there presently is no authority for awarding such damages in a rescission action. . $^{217}$

212. 111 N.J. Super. 124, 274 A.2d 865 (Dist. Ct. 1971), rev'd, 119 N.J. Super. 332, 291 A.2d 577 (App. Div. 1972), reinstated, 63 N.J. 460, 308 A.2d 17 (1973).

213. 63 N.J. 460,308 A.2d 17 (1973).

214. See id. at 469,308 A.2d at 22. See also Kline v. Burns, 111 N.H. 87, 276 A.2d 248 (1971), where the New Hampshire Supreme Court held that a tenant's complaint to recover "all rent paid" while the warranty was breached stated a cause of action. Such a cause of action was also upheld in an unreported California court of appeal decision, Ball v. Tobeler, 2 Civ. 38424 (2d Dist., - -, 1972), at 17. A copy of this decision can be obtained from the Western Center on Law and Poverty, 1709 W. 8th St., Los Angeles, Cal. 90017. Contra, Thompson v. Shoemaker, 7 N.C. App. 687, 173 S.E.2d 627 (1970). This decision might be explained, however, by the fact that North Carolina has not yet recognized the implied warranty of habitability.

Some courts have allowed the tenant to sue, apparently on a rescission thcory, for recovery of prepaid rents and security deposits where the tenant vacated because of a breach of the implied warranty. See Buckner v. Azulai, $251 \mathrm{Cal}$. App. 2d 1013, $59 \mathrm{Cal}$. Rptr. 806 (Los Angeles Sup. Ct., App. Div. 1967); Lemle v. Breeden, 51 Hawaii 426, 436, 462 P.2d 470, 476 (1969); Pines v. Perssion, 14 Wis. 2d 590, 597, 111 N.W.2d 409,413 (1961).

215. Cal. Crv. Code $\$ 1692$ (West 1973). See also Runyau v. Pacific Air Industries, 2 CaI. 3d 304, 466 P.2d 682, 85 Cal. Rptr. 138 (1970) (economic loss).

216. See note 202 supra.

217. Punitive damages are available if the tenant can show fraud or oppression in the making of the contract. See Car. CIv. Code $\$ 1689$ (b)(1) (West 1973). See also Ward v. Taggart, 51 Cal. 2d 736, 336 P.2d 534 (1959).

Practice note-a comparison of general damages and "retrodctive rent abatement": Where the tenant wishes to remain in possession of the premises, he cannot rescind, for rescission terminates the agreement, CAL. Crv. CODE $\$ 1688$ (West 1973), and with its termination the tenant must restore the premises to the landlord. See note 220 supra. Thus, to remain in possession the landlord must elect general dainages rather than rescission.

Although the tenant who has vacated may include alternative claims for damages and rescission, see CAI. Civ. Code $\$ 1692$ (West 1973); 2 B. Witkin, Californan ProCEDURE 981-82, 1965-72 (2d ed. 1970), before judgment he will have to elect which remedy he prefers, for recovery on both would allow duplicate and inconsistent recovery. See Cal. Civ. Code $\$ 1692$ (West 1973); 1 B. Witkin, Summary of California LaW 


\section{Specific Performance and Declaratory Relief}

Specific performance of the implied warranty of habitability should be a proper remedy for the tenant in most cases where he proves a breach of warranty and wishes to stay in possession. The remedy at law-damages-is inadequate, because the measure of damages is quite uncertain ${ }^{218}$ and the warranty relates ito land, which is traditionally considered unique. ${ }^{219}$ The court in Javins expressly included

531 (8th ed. 1973). In electing a remedy it would appear that the general damage cause of action is preferable to the cause of action for "retroactive rent abatement" in that the general damages theory holds the potential for a much higher monetary award in cases where the breach was very serious and the contract rent was low. Thus, consider a case where the contract rent is $\$ 100$ and the fact-finder.decides that the breach was so serious that the tenant has suffered discomfort and inconvenience worth $\$ 150$. Under a claim for general damages, the tenant recovers $\$ 150$. Claiming rescission, the tenant can recover only $\$ 100$, the difference between the contract rent $(\$ 100)$ and the reasonable rent (zero). This difference results froin the fact that, while in the rescission claim the contract rent places an upper limit on the tenant's recovery, the contract rent should be irrelevant in a general damages claim.

There may be additional reasons to elect the claim for damages for breach of implied warranty rather than rescission. First, punitive damages may be available for breach of the implied warranty, see note 202 supra, while they are probably not available under a rescission claim. See note 217 supra. Second, where the lease or rental agreement provides for attorney's fees for the landlord who wins a suit to enforce the agreement, the tenant may recover attorney's fees in an action for damages for breach of the implied warranty, even if the agreeinent provides attorney's fees only for the landlord. See CAL. Civ. Code $\$ 1717$ (West 1973). But where he sues to rescind, the tenant might be held to have rescinded the attomey's fees provision along with the rest of the agreement, thereby forfeiting his right to attorney's fees. See Pickinpaugh v. Morton, - Ore. _, —, 519 P.2d 91, 94-95 (1974) (three judges dissenting). Contra, Morris v. Chevrolet Motor Div. of General Motors Corp., 39 Cal. App. 3d 917, 114 Cal. Rptr. 747 (4th Dist. 1974).

In view of these advantages of the general damage claim, and the absence of any apparent advantages of a rescission claim, there are strategic reasons why a tenant's attorney may decide not to include a rescission cause of action in the contplamt. The rescission claim may tend to confuse the issues. It may also tend to focus the fact-finder's attention on the contract rent as a limit of the tenant's recovery. A damages claim, unaccompanied by a claim for rescission, may provide the fact-finder with a frame of reference of discomfort and annoyance such that higher damages would be more likely, especially if the fact-finder is accustomed to associating higher figures with a very similar injury-pain and suffering.

There might be one situation where a suit for rescission is appropriate but a suit for damages is not. As discussed earlier, see text accompanying notes 21-48 supra, it is not clear if either the implied warranty doctrine or the illegal contract theory apply in California to defects present at the outset of the tenancy. If the courts decide that the illegal contract theory applies but not the warranty of habitalibity, then the tenant will not be able to claim damages under his rental contract, but he may be able to rescind it on the ground of illegality. See CAL. CTV. CODE $\$ 1689(b)(5)-(6)$ (West 1973); see also William J. Davis, Inc. v. Slade, 271 A.2d 412 (D.C. Ct. App. 1970).

218. See text accompanying notes 99-114 supra.

219. Cf. CAL. CIv. CODE $\$ 3387$ (West 1970); CAL. COMM'I CODE $\$ 2716$ (West 1964); 4 B. WITKIN, Sumarary of California LaW, 2802-03 (7th ed. 1960). On pleading a cause of action for specific performance, see 3 B. WITKIN, CALIForNIA ProcedURE, 2266-85 (2d ed. 1971). 
specific performance as one of the tenant's remedies for breach of the implied warranty. ${ }^{220}$ In California, however, there is some authority "deny[ing] specific performance of contracts which call for a series of acts requiring contimuous supervision, such as agreements for construotion and repair." 221 But as a noted commentator has pointed out, the cases do not apply this rule consistently, and "the better modern oases reject this doctrine and give specifio performance whenever it is practically feasible."222

Finally, in appropriate cases, the tenant may seek a declaratory judgment that the landlord lias breached the implied warranty and that the tenant is thereby entitled to certain remedies, such as rent withholding. ${ }^{223}$ Such relief was granted in Hinson $v$. Delis, where the tenant sought a judicial declaration obliging her "to make rental payments only after the defendant complies with his duty to substantially obey the housmg codes and make the premise liabitable."224

220. Javins v. First Nat'l Realty Corp., 428 F.2d 1071, 1082 n.61 (D.C. Cir.), cert. denied, 400 U.S. 925 (1970).

221. 4 B. WITKIN, SUMmary of California LaW 2814 (7th ed. 1960).

222. Id.

223. Cf. Cal. Code Ctv. Pro. $\S 1060$ (West 1974). See also 3 B. Witkin, CaliFORNIA PROCEDURE 2328-54 (2d ed. 1971).

224. Hinson v. Delis, 26 Cal. App. 3d 62, 71, 102 Cal. Rptr. 661, 666-67 (1st Dist. 1972).

This might be a wise course to follow if the tenant has important issues he wants decided on the appellate level, since an action for declaratory judgment is filed in superior court, with a right of appeal to the court of appeal. See, e.g., id. Note also that an action for declaratory relief has precedence on the superior court calendar. CaL. CODE CIV. PRo. \$1062a (West 1955).

Practice note-other remedies: Some additional causes of action whieh a tenant's attorney may wish to add to his complaint include nuisance, intentional or reckless infliction of mental distress, and unfair competition. Although these theories have not yet been accepted by California courts in suits based on a landlord's failure to repair, the conceptual breakthrough which the inplied warranty began may quickly change this.

If accepted, these additional causes of action offer extensive relief, as contrasted with the problematical relief which the implied warranty doctrine promises. Therefore, the tenant's attorney is well advised to combine these supplemental causes of action, thus gaining the advantages of each at little or no sacrifice.

If the actions of the landlord constitute a nuisance, the tenant might recover damages for discomfort and annoyance, mental distress and physical injury, see note 133 supra, as well as punitive damages, see Hutcherson v. Alexander, 264 Cal. App. 2d 126, 136, 70 Cal. Rptr. 366, 377 (5th Dist. 1968); Sturges v. Charles L. Harney, Inc., 165 Cal. App. 2d 306, 320-22, 331 P.2d 1072, 1080-81 (1st Dist. 1958), and an injunction requiring abatement of the nuisance. CAL. CoDE CIV. Pro. $\$ 731$ (West 1955); State ex rel. Brown v. Sussman, 235 So. $2 \mathrm{~d} 46$ (Fla. Dist. Ct. App. 1970). Nuisance is defined by statute as "[a]nything which is injurious to health, or is indecent or offensive to the senses, or an obstruction to the free use of property, so as to interfere with the comfortable enjoyment of life or property . . . ." CAL. CIV. CoDE $\$ 3479$ (West 1970). Material violations of lousing codes would seem to qualify as a "nuisance" under this definition, and in fact the Uniform Housing Code itself expressly considers certain violations to be a nuisance. UNIFORM Housing CODE $\S 401$ (1973 ed.); see also City of Bakersfield v. Miller, 64 Cal. 2d 93, 99-100, 410 P.2d 393, 397-98, 48 Cal. Rptr. 889, 


\section{VI}

\section{RETALIATION}

The effectiveness of any of the tenant's remedies for breach of the implied warranty will be substantially diminished if the tenant is

893-94 (1966), cert. denied, 384 U.S. 988 (1966).

Many tenants, it would seem, will be able to obtain standing to sue on a nuisance theory. Material code violations should permit the tenant to show special injury from the public nuisance as the statute requires. See Cal. Crv. Code $\$ 3493$ (West 1970); Wade v. Campbell, 200 Cal. App. 2d 54, 59-60, 19 Cal. Rptr. 173, - (5th Dist. 1962). While the community as a whole certainly suffers from the cumulative effect of code violations in many buildings, they do not suffer so greatly or directly as the tenant of the specific building with such violations.

While most nuisance cases involve a defendant whose acts are committed on a piece of land apart from the plaintiff's land, this is not required by statute, see CAL. Crv. CoDE $\$ 3479$ (West 1970), and there is no good reason to impose such a requirement. See W. Prosser, The Law of Torts 594-95 (4th ed. 1971); see also Acadia, California, Ltd. v. Herbert, 54 Cal. 2d 328, 338, 353 P.2d 294, 300, 5 Cal. Rptr. 686, 692 (1960), where the court npheld a cause of action for failure to comply with an agreement to furnish water to plaimtiff's property, calling the failure "closely analogous to a trespass or a nuisance." See also Kornoff v. Kingsburg Cotton Oil Co., 45 Cal. 2d 265, 275, 288 P.2d 507, 513 (1955). Similarly, the contractual relationship between landlord and tenant does not preclude a nuisance theory. See Acadia, California, Ltd. v. Herbert, supra; Coole v. Haskins, 57 Cal. App. 2d 737, 135 P.2d 176 (1st Dist. 1943).

Another possible legal theory for defects in the rental unit is the tort of intentional or reckless infliction of mental distress, enabling the tenant to recover compensatory damages for mental suffering caused by the defects, as well as punitive damages. This tort is firmly established in California law, and has been held applicable to improper landlord harassment of tenants. See State Rubbish Collectors Assn. v. Siliznoff, 38 Cal. 2d 330, 240 P.2d 282 (1952); Aweeka v. Bonds, 20 Cal. App. 3d 278, 281-82, 97 Cal. Rptr. 650, 652 (1st Dist. 1971); Leavy v. Cooney, 214 Cal. App. 2d 496, 29 Cal. Rptr. 580 (2d Dist. 1963). It should also apply to a landlord who fails to repair, even though this involves a failure to act rather than an affirmative act. $C f$. Farvour v. Geltis, 91 Cal. App. 2d 603, 205 P.2d 424 (1st Dist. 1949). The theory covers reckless as well as intentional conduct. Restatement (SEconid) of TorTs $\$ 46$, Comment $i$ at 77 (1965), cited with approval in Spackman v. Good, 245 Cal. App. 2d 518, 530, 54 Cal. Rptr. 78, 84-85 (4th Dist. 1966). Thus it should not matter that the landlord did not know the defects would cause mental distress to the tenant if he had sufficient information to know that there was a high probability that the defects would cause distress.

If intentional infliction of mental distress is applied to the landlord's failure to repair, it would seem quite similar to the proposed tort of "slumlordism." See Sax \& Heistand, Slumlordism as a Tort, 65 Mich. L. REv. 869 (1967); cf. Evans v. Does, 283 So. 2d 804, 807 (La. Ct. App. 1973). See also Quesenbury v. Patrick, (1972-74 Transfer Binder) CCH Pov. L. RPTR. If 15,803 (Colo. County Ct. 1972).

A third theory which might apply here is unfair competition. As used in California unfair competition includes unlawful business practices whether they are injurious to consumer or competitor. See CAL. Crv. CoDE $\$ 3369$ (West 1970); Barquis v. Merchants Collection Ass'n, 7 Cal. 3d 94, 108-13, 496 P.2d 817, 827-31, 101 Cal. Rptr. 745, $755-59$ (1972). As a result, unlawful competition may be enjoined in an action brought by any person imjured by the defendant's acts, even if the plaintiff is a consumer rather than a competitor of the defendant. Id. Under this theory, the tenant might seek to remedy code violations not merely in his own apartment, but in all buildimgs operated as part of the landlord's "business." In an unpublished California court of appeal opinion, this right was upheld in an action against a landlord who refused to repair. See Ball v. Tobeler, 2 Civ. 38424 (2d Dist., - - 1972). 
afraid to use them. This fear is quite realistic. Because of housing shortages, ${ }^{225}$ the tenant does not want to risk losing his dwelling, even if it is substandard. Yet the law provides that a landlord may generally evict or raise the rent on a month-to-month tenancy for any or no reason, simply by giving a 30 -day notice to that effect. ${ }^{220}$ While the tenant who withholds rent because of a breach of warranty might invoke Green to defeat an eviction action based upon a three-day notice to pay rent or quit, he would seem helpless against an eviction action based on a 30-day notice which simply terminates the tenancy, making no reference to the failure to pay rent.

This danger was recognized by commentators soon after Javins was decided. ${ }^{27}$ Indeed, it was not much longer before courts also noted patterns strongly indicating retaliatory eviction. In Cooks $v$. Fowler, ${ }^{228}$ the court expressed concern over "the apparently rising incidence of possessory actions based on notice to quit following closely on the heels of possessory actions based on nonpayment of rent." ${ }^{220}$

\section{A. Allowing the Defense}

While the law concerning retaliatory evictions has developed steadily over the last few years, ${ }^{230}$ application of the doetrine to this situation seems at first glance quite difficult. There is no good reason not to prevent a landlord from evicting his tenant in retaliation for such acts as the tenant's reporting code violations to a city agency, ${ }^{281}$ joining

Appellate briefs are available which set out these three theories (and other, less viable, theories) more extensively than they are here. A copy of the brief in Arguellas v. Cortez, 1 Civ. 10639, may be obtained from National Housing and Economic Development Law Project, 2313 Warring St., Berkeley, California 94707. Copies of the briefs in Soria v. Fieberling, 1 Civ. 32102, and Ball v. Tobeler, 2 Civ. 38424, may be obtained from the Western Center on Law and Poverty, 1709 W. 8th St., Los Angeles, California 90017.

225. Green v. Superior Court, 10 Cal. 3d 616; 625, 517 P.2d 1168, 1173, 111 Cal. Rptr. 704, 709 (1974).

226. CaL. CIv. Code $\$ 1946$ (West Supp. 1974).

227. In large measure, the scope and effectiveness of tenant remedies for substandard housing will be determined by the degree of protection given tenants against retaliatory actions by landlords. If a landlord is free to evict or otherwise harass a tenant who exercises his right to secure better housing conditions, few tenants will use the remedies for fear of being put out on the street.

Daniels, Judicial and Legislative Remedies for Substandard Housings Landlord-Tenant Law Reform in the District of Columbia, 59 GEo. L.J. 909, 943 (1971). See also Note, Landlord-Tenant, 84 HARV. L. REv. 729, 737 (1971).

228. 437 F.2d 669 (D.C. Cir. 1971).

229. Id. at 673.

230. See Moskovitz, Retaliatory Eviction-A New Doctrine in California, 46 CaLIF. ST. B.J. 23 (1971) [hereinafter cited as $A$ New Doctrine]; California Eviction DEFENSE MANUAL, supra note $13, \S 9.25$, at 82 (1971).

231. See Edwards v. Habib, 397 F.2d 687 (D.C. Cir.), cert. denied, 393 U.S. 1016 (1968). 
a tenant organization, ${ }^{232}$ or using his repair-and-deduct remedy. ${ }^{233}$ But where the landlord's attempted eviction is based upon the tenant's assertion of rights under the implied warranty of habitability, there appears to be good reason not only to permit but indeed to require eviction if the tenant's assertion was valid. After all, the housing codes themselves forbid occupancy of a dwelling which violates the codes. ${ }^{234}$

This superficially appealing distinction, however, was very carefully analyzed and rejected in Robinson v. Diamond Housing Corporation, ${ }^{235}$ an extremely sophisticated opimion by the same court which decided Javins. Robinson was decided almost four years after the landlord first atteinpted to evict the tenant. ${ }^{236}$ The landlord filed its first eviction suit for nonpayment of rent, but lost to the tenant's defense of illegal contract. ${ }^{237}$ Taking note of this decision, the landlord in its second eviction suit reasoned that the proven illegal contract voided the rental agreement, thus making the tenant a trespasser. Again the court disagreed. The rental agreement, it held, was not rescinded, but inerely unenforceable; the defendant therefore became a tenant at sufferance whose tenancy could be terminated on 30 days notice. ${ }^{238}$ The third eviction action, the subject of the Robinson opinion, followed after the landlord served the suggested 30-day notice to vacate and the tenant refused to comply. The tenant raised the defense of retaliatory eviction; the landlord responded, alleging an intent to take the unit off the market. ${ }^{239}$ The trial court granted the landlord's motion for summary judgment. ${ }^{240}$

In Robinson, the court of appeals reversed, holding that the retaliation defense was available under these facts. Accordingly, it ordered a trial to determine if the landlord intended its 30-day notice to punish

232. See Hosey v. Club Van Cortlandt, 299 F. Supp. 501 (S.D.N.Y. 1969).

233. Schweiger v. Superior Court, 3 Cal. 3d 507, 476 P.2d 97, 90 Cal. Rptr. 729 (1970).

234. UNIFORM HOUSING CODE $\$ 204$.

235. 463 F.2d 853 (D.C. Cir. 1972). See Note, Landlord and Tenant, 18 Vill. L. REv. 1119 (1973).

236. The court observed: "If lawsuits were won by perseverance alone, Diamond Housing could hardly lose this suit." 463 F.2d at 857. This tribute to the perseverance of the landlord neglects the tenacity of the tenant and the tenant's attorneys, to which this case stands as a fitting monument.

237. The defects existed at the outset of the tenancy. The court citing Brown v. Southall Realty Co., 237 A.2d 834 (D.C. Ct. App. 1968), held that this fact proved the illegal contract claim. Diamond Housing Corp. v. Robinson, 257 A.2d 492, 495 (D.C. Ct. App. 1969).

238. Id.

239. The landlord also alleged an unwillingness to make the needed repairs. 463 F.2d at 859 .

240. The trial court found that it "would seem to be the height of absurdity to permit retaliation, at this juncture, even to be entertained." Id. 
the tenant for asserting illegal contract as a defense to the first action. ${ }^{241}$ In its analysis the court first took notice of evidence that retaliatory actions by landlords were being used to blunt the effectiveness of tenant remedies granted by Javins ${ }^{242}$ and Brown v. Southall Realty $C_{0}{ }^{243}$ It reasoned further that this possibility is not necessarily absent where the landlord intends to take the unit off the rental market, since he might be doing it "selectively in order to 'make an example' of a troublesome tenant who has the temerity to assert his legal rights in court."244 Finally, it noted the public policy against courts allowing themselves to be used as instruments to punish tenants for exercising legal rights, at least where the exercise assists in enforcing housing codes. ${ }^{245}$ Therefore, the court concluded, it would not enforce an eviction even to take a unit off the market if the action were in retaliation for a tenant's asserting rights granted by Javins or Brown.

Nor was the court persuaded that a housing code provision which forbids both the tenant's occupancy and the landlord's permitting occupancy of a substandard building precludes a retaliation defense. The landlord faced with sucl a provision, it felt, would be estopped from asserting the tenant's violation, since the landlord's neglect of his duty caused the building to be substandard. As for the landlord's own violation of the provision, the court felt such violation was easily remedied, since the landlord could make the necessary repairs rather than evict the tenant. ${ }^{246}$

While the Robinson analysis appears to be quite sound, the court might have overlooked a simpler route to the same end: One of the main reasons why the court had adopted the implied warranty doctrine in the first place was that tenants did not have the bargaining power to get express warranties, because of housing shortages. But where such shortages exist, the likelihood that retaliatory evictions will "chill" tenants' assertions of the implied warranty doctrine will be high, since the tenant has few or no alternative lousing choices. This being so, it would be anomalous in the extreme to allow landlords to exploit one

241. 463 F.2d at 867.

242. Javins v. First Nat'l Realty Corp., 428 F.2d 1071 (D.C. Cir.), cert. denicd, 400 U.S. 925(1970).

243. 237 A.2d 834 (D.C. Ct. App. 1968). See also Cooks v. Fowler, 437 F.2d 669 (D.C. Cir. 1971) and text accompanying note 228 supra.

244. 463 F.2d at 860.

245. The court relied on Edwards v. Habib, 397 F.2d 687 (D.C. Cir. 1968), its earlier decision forbidding evictions in retaliation for a tenant's reporting code violations to a city agency. In addition, the court noted that the City Council had recently adopted a provision prohibiting evictions in retaliation for asserting the defense of illegal contract. 463 F.2d at 857 n.1.

246. 463 F.2d at 868-69. 
of the very bases ${ }^{247}$ for the new doctrine to defeat the doctrine itself. This reasoning would apply equally in California, as Green also relied on the housing shortage and its effect on tenant bargaining power. ${ }^{248}$

\section{B. Proving Retaliatory Motive}

Developing a basis in reason for extending the retaliation defense for use with the implied warranty doctrine, however, is the simpler task. ${ }^{249}$ Implementing the defense raises far unore difficult issues, and among these proving retaliatory motive is perhaps the most troublesome. Some basic approaches for proving a landlord's retaliatory motive are discussed in detail elsewhere. ${ }^{250}$ While proving such a motive is likely to be difficult in any case, it would appear to be particularly difficult in a situation like Robinson, where the landlord can allege two justifications for evicting generally not available in other retaliation cases: the tenant is not paying the rent, and the landlord wishes to remove the unit from the rental inarket.

On this problem, too, the Robinson opinion's careful analysis furnishes some helpful guidance. The court acknowledged that the basic issue of fact in a retaliation case is the landlord's subjective state of mind: "If the landlord's actions are motivated by a desire to punish the tenant for exercising his rights or to chill the exercise of similar

247. Javins v. First Nat'l Realty Corp., 428 F.2d 1071, 1079 (D.C. Cir.), cert. denied, 400 U.S. 925 (1970).

248. 10 Cal. 3d at 625, 517 P.2d at 1173, 111 Cal. Rptr. at 709 (1974).

249. Indeed, in California the Civil Code arguably provides statutory grounds for prohibiting evictions in retaliation for the tenant's assertion of rights under the imphed warranty doctrine. CAL. CTV. CODE $\$ \$ 51-52$ (West Supp. 1974) (prohibiting "all arbitrary discrimination by business establishments"). In re Cox, 3 Cal. 3d 205, 216, 474 P.2d 992, 999, 90 Cal. Rptr. 24, 31 (1970). These sections have been interpreted to include landlords. See Swann v. Burkett, 209 Cal. App. 2d 685, 26 Cal. Rptr. 286 (1st Dist. 1962); cf. Flowers v. John Burnham \& Co., 21 Cal. App. 3d 700, 98 Cal. Rptr. 644 (4th Dist. 1971). The defense that an eviction is based on such arbitrary discrimination is available in an eviction action. See Abstract Investment Co. v. Hutchinson, 204 Cal. App. 2d 242, 22 Cal. Rptr. 309 (2d Dist. 1962). See also CalrForNia EvicTION DEFENSE MANUAL, supra note $13, \S 9.30$, at 87; A New Doctrine, supra note 230, at 29-31. Where the landlord's dominant purpose for evicting is to retaliate against the tenant for exercising his rights under Green, it may fairly be said that the landlord is arbitrarily discriminating against the tenant.

Moreover, California law prohibits evictions under conditions where the landlord "has as his dominant purpose retaliation against the lessee because of . . . his complaint to an appropriate governmental agency as to tenantability of a dwelling." CAI. CIV. CODE $\$ 1942.5$ (West Supp. 1974). When the tenant raises an implied warranty defense in an eviction action, or when he files an independent action against the landlord for breach of the implied warranty, he is "complain[ing] to an appropriate governmental agency"-the court-"as to tenantability of a dwelling." An eviction in retaliation for such "complaining," therefore would seem to be barred by section 1942.5.

250. See A New Doctrine, supra note 230, at 31-33; CALIFORNIA EVICTION DEFENSE MaNUAL, supra note $13, \$ \$ 9.25,13.34$, at $82,125$. 
rights by other tenants, then they are impermissible."251 The factfinder, however, can judge the landlord's state of mind "only by examining its objective inanifestations."252 Thus, applying this rule the court established a presumption of retaliatory intent whenever the landlord's conduct has the inherent effect of deterring tenants in the exercise of their rights. ${ }^{253}$ Such "inherently destructive" conduct, the court held, necessarily includes "[a]n unexlained eviction following successful assertion of a Javins or Southall Realty defense." 254 This in turn raises the presumption, requiring the landlord "to rebut it by demonstrating that he is motivated by some legitimate business purpose rather than the illicit notive which would otherwise be presumed."255

It is in defining "legitimate business purpose" that the intriguing issues arise. The desire to remove a tenant simply for withholding rent is, of course, not legitimate. Simce Javins and Southhall Realty grant the tenant the right to stop paying rent, the landlord who invokes this reason is trying in effect to evict the tenant for asserting his legal rights. But where repairs are impossible or infeasible, ${ }^{258}$ or cannot be made during occupancy, ${ }^{257}$ or where the intent to remove the unit from the market is accompanied by a showing of financial mability to make repairs $^{258}$ or by other convincing justification, ${ }^{250}$ or where the landlord desires to go out of business entirely, ${ }^{260}$ the landlord might well demonstrate a legitimate business purpose.

In each case the landlord unust show that the asserted purpose is not a subterfuge. For instance, where the impossibility or infeasibility of repair justifies eviction, the landlord may not eviot the troublesome tenant and then rent to another, for this course of action could be explained only by a desire to punish the foriner tenant. ${ }^{201}$ Similarly,

251. 463 F.2d at 865 .

252. Id.

253. 'Thus when the landlord's conduct is 'inherently destructive' of tenants' rights, or unavoidably chills their exercise, the jury may, under well recognized principles, presume that the landlord intended this result." $I d$.

254. Id.

255. Id.

256. Id.

257. Id. at 866 n.20. Compare Silberg v. Lipscomb, 117 N.J. Super. 491,285 A.2d 86 (Dist. Ct. 1971), where the court held that the landlord's failure to consider whether repairs could be inade while the tenant was in possession showed that one of his motives in evicting was retaliation.

258. 463 F.2d at 866 n.20.

259. Id.at 866 n.21.

260. "There would be severe constitutional problems with a rule of law which required an entrepreneur to remain in business against his will." Id. at 867 .

261. Id. at 866 n.20. The court did not explain how tenant might attack such a course of action. Suppose the landlord rebuts the presumption of retaliation by showing he is unable to repair, thus winning the eviction suit. After receiving judgment and ousting the tenant, he rents to a new tenant. What can the old tenant now do? The best 
while certain repairs legitimately require that the tenant temporarily vacate the premises, courts must insist upon a convincing demonstration of that necessity so that it does not become simply a removal device which chills the assertion of rights by other tenants. Finally, the inere existence of a legitimate business purpose does not, of course, automatically rebut the presumption of retaliatory intent. The fact-finder must, in addition, find that the landlord was in fact motivated to evict by that legitimate purpose rather than by a desire to punish the tenant. 202

So far, Robinson is the only reported case which thoroughly analyzes the problein of proving retaliation, an analysis sorely needed. Although the law permitting the defense of retaliation has been developing steadily, its practical value to tenants has been questionable. Since retaliation is a defense, under customary rules of evidence the tenant has the burden of proving it. But tenants (and their attorneys) often beheve they will have little chance of convincing the fact-finder that the landlord's purpose in bringing the eviction action is retaliation. The landlord usually finds some other apparently legitimate reason for evicting, and thus the tenant almost always faces an uphill battle in attempting to prove that this was not the motivating reason. ${ }^{203}$ Knowing that these obstacles lay ahead, the tenant is quite likely to forego the exercise of his legal rights in the first place, since they may lead to an eviction motivated by an unprovable desire to retaliate. Robinson, however, establishes a presumption that an eviction retaliatory in effect is also retaliatory in intent, thus demanding a careful examination of the landlord's explanation for his action. This significant shift in burden and focus should help to reassure tenants that they may exercise their rights with some sense of security that the law will protect them in fact as well as in the abstract. Moreover, the accominodation

approach might be to move to set aside the judgment and for a new trial, if the time limits for such a motion have not elapsed. See CAL. CODE Crv. Pro. § 659 (West 1974). The ground for the motion will be "newly discovered evidence"-the rental to the new tenant-which strongly reveals the landlord's true motive in evicting. See Cat. Code Civ. Pro. \$ 657(4) (West 1974). See also 5 B. WitkIn, Californta Procedure 3606-09 (2d ed. 1971). If the time to move for a new trial has run, the tenant might have a tort action for damages based on the theory of "abuse of process" or "malicious prosecution of a civil action." See 4 B. WrTkIN, SUMmary of Cal IFORNIA LAw 253842 (8th ed. 1974). Cf. Aweeka v. Bonds, 20 CaI. App. 3d 278, 97 Cal. Rptr. 650 (1st Dist. 1971).

262. $463 \mathrm{~F} .2 \mathrm{~d}$ at 867 . For a discussion of how strong the retaliatory motive must be in relation to other motives, see California Eviction Defense Manual, supra note $13, \S 13.36$, at 126, and $A$ New Doctrine, supra note 230, at 31-32. See also Silberg v. Lipscomb, 117 N.J. Super. 491, 496, 285 A.2d 86, 88 (Dist. Ct. 1971) (landlord's decision to evict must have been "reached independent of any consideration of the activities of the tenant protected by the statute" (emphasis added)).

263. In some cases, of course, circumstantial evidence might be available to meet this problem. See $A$ New Doctrine, supra note 230, at 31-33. 
reached by Robinson seems quite logical and reasonable. Since the landlord is in the best position to furnish evidence of his own motives, placing the burden upon him appears far from unfair. ${ }^{264}$

\section{Scope of the Retaliation Defense}

While Robinson involved an attempt to evict a tenant in retaliation for the tenant's raising an illegal contract defense, there is no reason its rationale must be confined to these facts. The ultimate boundaries of this defense are yet unclear. In exploring for its logical scope, however, one must keep in mind both the action taken by the tenant and the landlord's conduct in response to it.

As for actions of the tenant, assertions under the implied warranty theory deserve as much protection as assertions under the illegal contract theory. Both, after all, are based on the housing codes. Indeed, the court in Robinson expressly included implied warranty claims in its protections. $^{285}$ The defense, it would seem, should also protect a tenant's filing a suit against the landlord on a Javins or Southall Realty theory. Such suits have been specifically authorized by case law, ${ }^{280}$ on theories derived largely from the housing codes. The Robinson rationale, therefore, should protect as well against this kind of retaliation. ${ }^{287}$ Similarly, where the tenant merely complains to the land$\operatorname{lord}^{268}$ about the condition of the premises, this act should also be protected from retaliation. In order for the tenant to later assert an implied warranty claim, the landlord must have had notice of the defects, ${ }^{209}$ and some courts have specifically stated that such notice must be given by the tenant. 270 If assertions of the implied warranty claim are protected, then it follows that preconditions to such assertions

264. California's retaliation statute also provides in some cases for shifting the burden of proof to the landlord. See Cal. Civ. CoDe $\$ 1942.5$ (d) (West 1974);

265. 463 F.2d at 858. See also note 282 infra and accompanying text.

266. See note 192 supra.

267. Practice note: A convenient way to protect against the possibility of such retalitation is to request-in the suit filed against the landlord--a temporary restraining order and preliminary injunction against any 30-day notice to vacate being served on the tenant, any eviction action filed against the tenant, or any notice of rent increase being served, without a prior showing of "good cause" to the court in which the tenant's suit is filed. These motions might be based on the tenant's allegation in the complaint that he is informed and believes that the landlord will try to retaliate against the tenant when he is served with the tenant's lawsuit. A temporary restraining order of this type was granted in Rose v. Hewes Co., Alameda County Super. Court No. 393347, Sept. 16, 1969. See 2 National Housing and Development Law Project, HaNddook on Housing LAW ch. III, at 28-29 (1970).

268. If the tenant complained to a city agency, he would clearly be protected from retaliation. See CaLIfornia Eviction Defense Manual, supra note $13, \S 9.28$, at 86 87; A New Doctrine, supra note 230, at 28.

269. See notes $94-95$ supra.

270. See note 94 supra. 
must also be protected. In addition, in the great bulk of cases complaints to landlords probably result in repair of the defects, thus furthering the purpose of the housing codes and saving the courts the expense of litigating a great number of implied warranty cases.

Landlord responses in retaliation may take several forms. The stated intent of Robinson to forbid any landlord conduct which "is 'inherently destructive' of tenants' rights, or unavoidably chills their exercise,"271 should prohibit retaliatory rent increases as well as retaliatory evictions. ${ }^{272}$ The tenant faced with such a rent increase, it would seein, may either refuse to pay it and claim retaliation at the subsequent eviction action, or sue to enjoin the increase. ${ }^{273}$ Indeed, the reasoning logically extends as well to retaliatory sales where the sale of the building is intended to lead to the eviction of the tenant. ${ }^{274}$

271. Robinson v. Diamond Housing Corp., 463 F.2d 853, 865 (D.C. Cir. 1972).

272. See also Aweeka v. Bonds, 20 Cal. App. 3d 278, 97 Cal. Rptr. 650 (1st Dist. 1971).

273. Id.

274. Robinson v. Diamond Housing Corp., 463 F.2d 853, 866 n.22 (D.C. Cir. 1972).

Practice note-ensuring application of correct law: If this Article reveals nothing else, it certainly demonstrates the importance and difficulty of several legal issues the courts will face in the near future. If the tenant's attorney wants appellate rulings on these issues, he will have to see that the appellate court receives a record which clearly presents them. This point was brought home in the companion case to Green, Hall v. Municipal Court, 10 Cal. 3d 641, 517 P.2d 1185, 111 Cal. Rptr. 721 (1974). In Hall the landlord sued to evict the tenant for nonpayment of rent, and the tenant raised an implied warranty defense. Over the landlord's objection, the trial court received the tenant's evidence on this issue, apparently relying on Hinson v. Delis. Id. at 643,517 P.2d at $1186,111 \mathrm{Cal}$. Rptr. at 722 . The landlord "apparently controverted at least some of the tenant's testimony," and the court ruled in favor of the landlord. Id. The tenant requested the court to issue findings of fact, but the court refused.

The supreme court denied the tenant's petition for writ of mandate, in effect affirming the trial court's ruling. The court rejected the tenant's claim that the trial court had failed to apply the implied warranty doctrine correctly.

Under established principles, of course, a lower court judginent is presumed correct, and when a lower court has made no specific findings of fact, it is presumed that the court made such implied findings as will support the judgment.

In the instant case the trial court made no explicit findings of fact, and thus, as the landlord suggests, on the present state of the record we must presume that the court's decision rests on a factual determination that no breach of warranty occurred, rather than on an erroneous legal determination that the breach of warranty of habitability could not be raised in an unlawful detainer action.

Id. at $643-44,517$ P.2d at 1186, 111 Cal. Rptr. at 722 (citations and footuote omitted).

The court lield that the trial court was not required to grant the tenant's request for findings. The law requires findings in municipal court only where the amount of the demand or the value of the property in controversy exceeds $\$ 1,000$. CAL. CoDE CIv. PRo. § 632 (West Supp. 1974). Here the demand was only for $\$ 160$, one month's rent. The "property in controversy" was the unexpired term of the tenant's lease. Since the tenant had only a month-to-month tenancy, the value of this property was clearly less than $\$ 1,000$. $10 \mathrm{Cal} .3 \mathrm{~d}$ at $644 \mathrm{n} .2,517$ P.2d at $1186 \mathrm{n} .2,111 \mathrm{Cal}$. Rptr. at $722 \mathrm{n} .2$. 


\section{CONCLUSION}

The effect the implied warranty of habitability might have on slum housing deserves a few concluding words. Some landlords have

In order to avoid the problem faced in Hall-where the attorney knew that the trial court's decision was based on a misapplication of the law rather than its view of the facts, but the record on appeal was not sufficient to persuade the appellate court of this - the tenant's attorney has several alternatives. First, there may be circumstances where findings are required. The landlord's demand often does exceed $\$ 1,000$, especially where he requests attorneys fees and treble damages in addition to past-due rent. Also, if the tenant has a lease for a specified term, the part of the term which has not expired when the landlord filed his suit is the "property in controversy." Id. The value of this property can be estimated by multiplying the number of remaining months in the term by the monthly rent. Thus, if the monthly rent is $\$ 150$ and seven months of the lease liave not yet run, the value of the property in controversy exceeds $\$ 1,000$.

Second, even if findings are not required, the court still bas the discretion to grnnt a party's request for them. Since one of the purposes of findings is to facilitate appellate review with minimum expense to the parties, a judge who is in sympathy with this purpose might grant the request. See Frascona v. Los Angeles Ry. Corp., $48 \mathrm{Cal}$. App. 135, 137, 191 P. 968 (2d Dist. 1920). See also 4 B. Witkin, Californin Procedure 3112 (2nd ed. 1971).

Third, while the absence of findings establishes a presumption "that the court made such implied findings as will support the judgment," 10 Cal. 3d at 643-44, 517 P.2d at 1186,111 Cal. Rptr. at 722, such a presumption may be rebutted by a record on appeal which demonstrates that there was no substantial evidence introduced to support the judgment. See 6 B. Witkin, California Procedure 4236-48 (2d ed. 1971). There are three methods of presenting such a record: with an agreed statement, a reporter's transcript or a settled statement. Car. RuLES of Court 124, 126, 127 (West 1974); 6 B. Witrin, CaIIFornia Procedure 4359-66. The agreed statement must be agreed upon by the landlord's attorney, so this will generally be unavailable. The reporter's transcript may well be expensive, particularly if the trial lasted more than a day or so. While the reporter's fees are costs recoverable by the prevailing party, CAL. Gov'T CoDE $\$ 69953$ (West 1972), California courts have yet to recognize an indigent's right to the transcript without payment of fees. See Kaufman v. Brown, 106 Cal. App. 2d 686, 688-89, 235 P.2d 632, 634 (4th Dist. 1951); Rucker v. Superior Court, 104 Cal. App. 683, 286 P. 732 (2d Dist. 1930); but see Lee v. Habib, 424 F.2d 891 (D.C. Cir. 1970). The settled statement may be the best way of preparing a record under the circumstanccs, although it may be difficult to prepare to the judge's satisfaction without a transcript to verify the attorney's memory or notes of the testimony. If the attorney's secretary heard the testimony and took shorthand notes of it, however, a transeription of these notes might be presented to the court by declaration or affidavit, to verify the proposed settled statement.

Finally, the Hall problem might be avoided by requesting a jury trial rather than a court trial. The tenant has a right to a jury trial in eviction cases, CAL. Code CIv. PRo. \$1171 (West 1972), and jury fees may be waived if the tenant's application to proceed in forma pauperis has been granted. Martin v. Superior Court, $176 \mathrm{Cal}$. 289, 168 P. 135 (1917). See also California Eviction Defense Manual, supra note 13, $\S 10$, at 93-98. The law applicable to the case will be contained in the court's instructions to the jury. If these instructions do not state the law correctly, the tenant's attorney may be able to slow reversible error. The record on appeal will contain the jury instructions in the clerk's transcript, CAL. RuLES of CouRT 125 (West 1974), whieh is usually much less expensive to prepare than the reporter's transcript. Also, there is a strong argument that the indigent appellant should not have to pay the costs of the clerk's transcript, even if the law requires payment of the costs of a reporter's transcript, for while the reporter is a private party the court clerk is not. See Roberts v. Superior 
argued that adoption of the doctrine would have a negative effect on housing for the poor by discouraging investunent in low-income housing, causing mcreased rents or abandonment or both. ${ }^{275}$ While there is much speculation, however, there is no reported evidence that advances in tenants' rights have caused this to happen in any significant degree. ${ }^{278}$ Indeed, it is highly questionable whether improved code enforcement, the very object of the implied warranty doctrine, tends to have these negative effects. ${ }^{277}$ In any event, it appears that our state and local legislative bodies, by adopting housing codes, have decided to take this chance-a sensible choice in view of the likely negative effects on the poor, and the rest of the community, of not requiring proper inaintenance. Moreover, whatever negative effects code enforcement has caused for low-income housing, lack of tenant participation in the code enforcement programs may be partly to blane. ${ }^{278}$

The imphed warranty of habitability permits significant tenant participation in code enforcement. By allowing tenants to decide when the codes should be enforced by withholding rent or filing affirmative lawsuits, the doctrine permits those persons who bear the greatest risk vis-à-vis code violations to decide whether enforcement or nonenforcement in any particular case creates the greater danger for thein. ${ }^{279}$ By giving the tenant the power to enforce the codes, the courts may have significantly helped enforcement, not merely by adding to the nuniber of enforcers, but also by placing the power to enforce in the hands of people who, due to self-interest, may make the best decisions

Court, 264 Cal. App. 2d 235, 238-39, 70 Cal. Rptr. 226, 229-30 (5th Dist. 1968). Of course, the tenant's attorney may well prefer a jury trial to a court trial for other reasons. The experience of many tenants' attorneys shows that trial court judges are often more favorably disposed toward landlords' interests than those of tenants, especially where new defenses such as the implied warranty of habitability are raised. This may be less true of jurors.

275. Cf. Mease v. Fox, 200 N.W.2d 791, 797 (Iowa 1972) (landlord claimed adoption of the implied warranty would "wreck our way of life").

276. See Robinson v. Diamond Housing Corp., 463 F.2d 853, 860 (D.C. Cir. 1972); Dooley \& Goldberg, A Model Tenants Remedies Act, 7 HARv. J. LEGIs. 357, 36468 (1970); Comment, Unlawful Detainer: Synopsis of California Law and Constitutional Considerations, 44 S. CaL. L. REv. 768, 808-10 (1971); Comment, California's New Legislation on a Landlord's Duty to Repair, 3 U.C. DAVS L. REv. 131, 150-54 (1971).

277. See Ackerman, Regulating Slum Housing Markets On Behelf of the Poor: Of Housing Codes, Housing Subsidies and Income Redistribution Policy, 80 YAIE L.J. 1093 (1971); Komesar, Return to Slumville: A Critique of the Ackerman Analysis of Housing Code Enforcement and the Poor, 82 YALE L.J. 1175 (1973); Ackerman, More on Slum Housing and Redistribution Policy: A Reply to Professor Komesar, 82 YALE L.J. 1194 (1973); Hartman, Kessler \& LeGates, Municipal Housing Code Enforcement and Low-Income Tenants, 40 J. AM. Inst. Planners 90 (1974).

278. See Hartman, Kessler \& LeGates, supra note 277.

279. Good advice from a well-informed attorney, of course, may help this decision to be a wise one. 
on whether enforcement is wise. Also, since most lawsuits are settled out of count, the tenant may be able to use the implied warranty doctrine as increased leverage to get a settlement agreement tailored to his specific needs as well as the resources of the landlord.

Still, there are indications that selective code enforcement-no matter how careful and intelligent the individual decisions-inust inevitably lead to rent increases, and that only a broad attack on every slum building in the community will minimize this effect. ${ }^{280}$ If this is true, then the implied warranty will be most effective if used by broadly-based commumity groups to conduct organized campaigns against slumlords. ${ }^{281}$ Besides being a useful tool of such groups, the implied warranty doctrine can also help to create such organizations in the first place. ${ }^{282}$ The growth of tenant umions in the past has been hampered largely by the illegality of the key tenant organizing tactic: the rent strike. When tenants withheld rent, they were evicted, and the organizing effort failed. The implied warranty, however, in effect legalizes the rent strike against slum landlords.

Perhaps more importantly, tenant organizations which come into being through the help of the implied warranty doctrine may be able to attain the sophistication and political influence to do something about the basic problem underlying the need for the implied warranty: lack of decent housing in adequate numbers of units for low-income people. While slumlords are not to be forgiven their sins, a major portion of the responsibility for slums falls on the government-federal, state, and local. Through redevelopment programs the government lias removed - without replacing - thousands of units of low-income housing. Public housing, FHA-subsidized housing, and the like offer some units for low-income people, but the potential of these programs has been stifled by inadequate funding and misperception of the needs of the poor. ${ }^{283}$ Tenant organizations can, and indeed have begun to, play a vital role in stopping those prograns which hurt the poor while pushing for those which help them. ${ }^{284}$ If the implied warranty doctrine helps even shightly to achieve this purpose, it could well be one of the most pragrnatically significant judicial innovations in our country's history.

280. See Ackerman, Regulating Slum Housing, supra note 277.

281. See Crescent Park Tenants Ass'n v. Realty Equities Corp., 58 N.J. 98, 275 A.2d 433 (1971), where the court held that a tenants' organization which formed a nonprofit corporation had standing to sue a landlord to enjoin him to make repairs.

282. See 2 National Housing and Development law Project, Handbook on Housing LAw ch. I, at 41-45 (1970).

283. See generally id.

284. See id. at 7-14. 


\section{California Law Review}

VoL. 62

DECEMBER 1974

No. 5

\section{BOARD OF EDITORS}

Editor-in-Chief

Bruce A. COHEN

Executive Editor

JANE W. HALL

Articles

BRUCE MaxTMOY

JoANNE B. Grossman

Pamela S. Jue

DOROTHY ROBINSON

EARL J. WATtS

Supreme Court Editor

ANN BRICR

Assistant Managing Editor

RICHARD M. TRAVIS

\section{Carol AmYX \\ MaNUEl AraUjo \\ DOROTHY BERNDT \\ Williamson B. C. Chang \\ JOHN DANNER}

\author{
Chuck Adams \\ THOMAS BARLETTA \\ JAMES A. BOWEN \\ HAROLd A. BROWN \\ KATHRYN J. BURKE \\ REgINALd ANTHONy Clay \\ ROBERT E. DARBY \\ JUDY A. FLYNN \\ LINDA FousT \\ Fred FRIEDMAN \\ Charles F. Gorder, Jr. \\ LAWRENCE Graze \\ J. MICHAEL HEMMER \\ JOEL G. HIRSCH \\ LAWRENCE A. HobeL
}

Managing Editor

H. LEE WATSON

Research

Douglas W. BecK

MICHAEL J. LAWSON

Membership

LAURA W. S. MACKLIN

Francis E. Fernandez

GaRy GreENFIELD

JUDITH DROZ KeYes

\section{Associate Editors}

ROBERT A. DESTRO

LANI LIU EWART

JOSEPH FERRARA

ALAN M. KATZ

JOHN BARNETT MARKS

RICHARD E. HYLAND

GEORge A. JUAREZ

KATHLEEN M. KeLLY

GARRY KOENIGSBERG

LEWIS A. KORNHAUSER

CORALTHA LEWTS

DANiEl B. Magraw, JR.

NeNA MaNLEY

EDWARD MARSHALL

JOHN B. MCNEECE III

JAMES L. MILLER

TONY MIRANDA

ERNEST A. NAGATA

Cratg N. Oren

ALAN PedLaR
Note \& Comment

ADRIAN ARIMA

KATHARINE T. BARTLETT

Alan M. Fenning

LAWRENCE L. HOENIG

Peter S. MUÑ̃oz

Norman Pine

Federico Castelan SAYre

RAND C. SCHMIDT

JAMES SEVERSON

EVELYN R. SinaIKo

STEPHEN STUBLAREC

LOUIS S. WELLER

Thomas JOHN MILIS

Howard M. MOFFETT

ARTHUR LARRY PASSAR

PaUL M. Rose

RALPH J. SHAPIRA

Phil Peters

ROBERT J. PETTLER

Thomas G. QUINN

JOHN D. ROBERTSON

ED ROYBAI

ANDY SAWYER

SuE ANN LEvIN SchIFF

MarJorie Maguire SHULtz

MARX B. SEYFERTH

CATHY R. SILAK

MARGaret S. SMITH

Elisabeth A. Werby

ALEX WIIES

RENIE EIKO YOSHIDA

DOUGLAS R. YOUNG
JEFFREY S. ALLEN 